\title{
Theft and Its Prosecution
}

On Monday 9 February 1756 dyer Giuseppe degli Agostini made his way to one of the criminal court's notaries to denounce a theft that had occurred the day before. ${ }^{1} \mathrm{He}$ described having had a pig slaughtered two months prior and keeping six salted pieces in his apartment near Porta Sant'Isaia. After his wife left the apartment door open when they went out, they found upon their return that some of their cured ham was missing. A trail of salt grains led them to the apartment of one of their fellow tenants, Catarina Benserati. This evidence was presented to Bologna's Tribunale del Torrone, and Catarina was brought in for questioning soon after. Catarina, a widowed Bolognese spinner, excused her actions by saying she had walked past the apartment, had seen the meat through the open door and had hidden it in her room - but only as a joke. She claimed she had intended to return it later, but was unable to do so since she was incarcerated in the meantime. The case was concluded when, a week later, the ham was returned to Giuseppe, and Catarina was released from custody that same day without a criminal sentence.

While in many ways atypical, this case serves well to illustrate some of the general characteristics and circumstances of the many quotidian thefts in early modern Bologna. For both male and female offenders, opportunistic thefts from houses by neighbours featured prominently among the cases passing through the criminal court. The example furthermore speaks to the specific position that female offenders held before the early modern Italian justice system. While thefts and other property offences formed an important focus of law enforcement, there is significant evidence that female property offenders like Catarina were disproportionally dismissed of criminal culpability. This chapter, which examines the gendered dynamics of theft in early modern Bologna, therefore aims to shed light on both of these aspects: on the differences and similarities in everyday practices of male and female offenders as well as on the legal attitudes that framed their encounters with the law in early modern Italy. It argues that the comparatively low share of female property offenders among the higher echelons of Bologna's criminal justice system was engendered by a pervasive culture of institutionalisation, peacemaking and judicial paternalism towards women.

1 ASвo, Torrone, 8179-2, fasc. 16. 
To this end, this chapter will start with a discussion of the legal attitudes towards thieving by the Bolognese authorities. Bologna's local criminal bylaws provide evidence for a continuing hardening of the attitudes towards property offending. They furthermore demonstrate that ideas about the prosecution and punishment of property crime were inherently gendered. The next part discusses various aspects of everyday practices of thieving based on the representative samples of denunciations and processi collected from the Torrone between the mid-seventeenth and mid-eighteenth centuries. Because of the small number of women in these representative samples, an additional set of theft processi involving female offenders has been collected to be able to scrutinise women's involvement in more detail. Based on these sources, this section examines the importance of theft among offenders denounced and prosecuted in early modern Bologna, the role of women in these cases, and the judicial treatment in practice, to point out two peculiarities of early modern Italy's legal culture: the pervasive peacemaking practices and the significant judicial indulgence towards women's involvement. Following this, the social characteristics of these property offenders will be discussed, suggesting that Bolognese thieves belonged to the working poor that incorporated occasional theft as part of their makeshift economies. The subsequent sections discuss what types of goods were stolen and where they were stolen from, and furthermore attempt to trace the journeys of these stolen goods through the urban environment. They suggest that the differences in practices and treatment of male and female thieves must be understood as existing alongside a wide range of shared behaviours, demonstrating the complexity of the relationship between thieving and dynamics of gender.

Property crimes in early modern Italy have received little scholarly attention, especially compared to elsewhere in Europe. Examinations of Italy's administration of criminal justice reveal the new political regimes' preoccupation with curbing the endemic violence as well as rural banditry rather than theft and other property offences. ${ }^{2}$ From a legal perspective Italy shared a similar preoccupation regarding theft with the rest of Europe. Based on legal treatises and

2 See, for example, Tedoldi, La spade e la bilancia, 119-135; C. Povolo, 'Aspetti e problem dell'amministrazione della giustizia penale nella repubblica di Venezia, secoli XVI-XVII,' in G. Cozzi (ed.), Stato, società e giustizia nella Repubblica Veneta (sec.XV-XVIII) (Rome:Jouvenence, 1980) 220-236. 
theological-ethical debates, Paolo Prodi argued that theft, from the twelfth century onwards, was increasingly conceptualised not only as a sin but also as an infraction of the concrete societal rules about the possession and use of goods. ${ }^{3}$ Combined with a fundamental change in Christian solidarity regarding poverty, this reconceptualization led to an expansion of repressive penal legislation concerning crimes against property and the prescription of increasingly heavy punishments for thieves, in Italy and elsewhere in early modern Europe.

In a normative sense, the Bolognese authorities indeed regarded property offences as grave violations of public and private order during the seventeenth and eighteenth centuries. Scholars have contended that criminal courts prosecuted these kinds of offences with great determination, even if the value of the stolen goods was quite low. ${ }^{4}$ In the Bolognese criminal bylaws, the prescribed penalties for property offences (or "theft and other similar offences" (furto, \& altri simili delitti)) were severe. The Bando Generale of 1610, promulgated by Legate Benedetto Giustiniani, prescribes a place in the pillory or whipping combined with banishment for a first-time thief without extenuating or aggravating circumstances. Thefts of great value as well as second-time offenders could, however, be punished with a 10-year sentence to the galleys and a third offence to death by hanging. With aggravating factors, death sentences were readily prescribed. ${ }^{5}$

It is generally assumed that the authorities' attitudes towards crimes against property offences continued to harden during the eighteenth century. ${ }^{6}$ According to some scholars, a growing social concern about the increased unemployment and impoverishment of the urban population due to the textile industry crisis formed the backdrop to this development in Bologna. ${ }^{7}$ The criminal bylaws are sources in which such an increasing concern with property offences was most visible. Legate Fabrizio Serbelloni's 1756 Bando Generale is the first heavily revised summation of criminal bylaws since the beginning of the seventeenth century and is viewed as a reflection of the changing penal attitudes in Bologna. ${ }^{8}$ This summation of the criminal bylaws for the first time

3 P. Prodi, Settimo non rubare. Furto e mercato nella storia dell'Occidente (Bologna: Il Mulino, 2009) 108, 208-209, 244.

4 Angelozzi and Casanova, Donne criminali, 243.

5 Bando generale Giustiniano 1610, 26-29.

6 For the situation in England, see Gray, Crime, prosecution and social relations, 68; J. McEwan, 'Negotiating support. Crime and women's networks in London and Middlesex, c.1730-1820' (Unpublished PhD thesis, University of Western Australia, 2008) 147.

7 Angelozzi and Casanova, Donne criminali, 243; Angelozzi and Casanova, La giustizia criminale a Bologna nel XVIII secolo, 142-147.

8 Angelozzi and Casanova, La giustizia criminale a Bologna nel XVIII secolo,219-220. 
explicitly discusses the social dangers of theft. The opening paragraphs on theft state that this crime was in some ways considered to be more dangerous than homicide. The reasoning for this was as follows: while homicide was a great evil, it was essentially not repeatable. Theft on the other hand could be repeated endlessly, which made it most pernicious to both public and private order. ${ }^{9}$ Although the rigorous punishment of theft may seem cruel and unjust, the document continues, the growing human malice and proclivity for this offence required such sentencing, because without it, it would be impossible to cope with the "impetuous torrent of thieves."10

Moreover, compared to the older bylaws, the 1756 Bando Generale defines in much more detail what is understood as theft, which categories of indictable property offences are distinguished and what the corresponding sentences were to be. In these new criminal bylaws the value of the stolen goods, recidivism and aggravating circumstances were key determinants for the severity of the punishment (see table 19). 'Normal' theft was called furto semplice and consisted of a range of larcenous activities. Aside from the act of stealing itself, it also covered the receiving of stolen goods. In line with juridical opinions elsewhere in early modern Europe, the Bolognese authorities considered receiving stolen goods to be just as bad as stealing itself." According to Serbelloni's Bando Generale of 1756 , these two acts should be treated and punished in the same way, since one could not operate without the other. ${ }^{12}$ Three types of receiving actors are distinguished. First, those who had acted in good faith, buying from acquaintances, were not subject to punishment aside from having to return stolen goods without reimbursement of money spent. Those who had acted in 'bad faith,' for example by buying goods from strangers or at night not only had to return the goods or pay a monetary substitute, but if they sold the goods on they were furthermore liable for prosecution by the criminal court. A third category describes the true accomplices, who faced the same sentences as thieves. For pickpockets (borsaiolo) and purse cutters (tagliaborse) the same punishment guidelines were prescribed as for thieves.

9 'L'Omicidio seguito, che sia eg’è certamente un grandissimo male, mà non è di sua natura reiterabile; allicontro il Furto ha in se questa pessima essenza, e da questa reiterazione seguendono la frequenza diviene perniciosissimo alla pubblica, e privata quiete, e di pessimo esempio." See Bando generale Serbelloni 1756, 39.

Ibidem: "Sembrerà a tal'uni queste pena crudele, ed ingiusta [... ma] vedendosi l'umana malizia sempre più accrescersi, ed esser facile, a proclive a questo Delitto, è stato più che necessario esacerbar le pene control il medesimo, senza le quali si renderebbe impossibile di far argine ad un Torronte così impetuoso di Ladri." 
The category of furto qualificato considered aggravating factors that, according to the norms of the 1756 Bando Generale, included the use of fake keys, lock picking, climbing walls with ladders or forcing windows or doors open. Even if the value of the stolen goods was relatively low, these kinds of thefts were punishable by death. The criminal bylaws state that this was due to people having no other options to protect their belongings than through

these locks and walls. Their violation was thus interpreted as a public offence against the papal prince who was responsible for the protection of the city and its houses. ${ }^{13}$ Another aggravating factor that is mentioned separately was connected to labour relations. Responding to a perceived need to sanction this particular behaviour, Serbelloni's Bando Generale pays specific attention to domestic thefts, i.e. thefts committed by domestic servants or employees. As they were considered deceitful and difficult to defend oneself against, these kinds of thefts were subject to harsher punishments. ${ }^{14}$ Compared to the furto semplice, the prescribed sentences were always a tier more severe. For example, while a first-time theft of an item worth $5^{\circ}$ to 100 lire was prescribed a sentence of 5 years to the galleys in case of a simple theft, a theft of the same value by domestic servants would lead to a 7-year sentence.

Although quite specific in the punishments it prescribed per crime category, the criminal bylaws left ample room for the judge's discretion. In the introduction of Cardinal Benedetto Giustiniani's Bando Generale of 1610, it is declared that the inviolable laws must be observed by "each person of any sex, status, level, quality or condition."15 However, early modern justice was tailor-made and in Bologna the judge was also explicitly given the discretion to take into account the causes, persons, places, time, the 'quality' and quantity, and other mitigating or aggravating circumstances when passing judgement. ${ }^{16}$ That factors like age and gender were considered among the 'personal qualities' that could lead to a reconsideration of the prescribed punishments can be observed in the core text of Giustiniani's Bando Generale. Being younger than fourteen years of age, for example, exempted offenders from the death penalty for theft, and women were not to be sentenced to three pulls of the cord (strappado) for the taking away of possessions from fields or gardens as men were, but rather to three months of incarceration. ${ }^{17}$ Similar distinctions can also be observed for other kinds of offences.

\footnotetext{
13 Bando generale Serbelloni 1756, 42-43.

14 Ibidem, 44-46; Angelozzi and Casanova, Donne criminali, 93.

15 Bando generale Giustiniano 1610, 4.

16 Ibidem, 72.

17 Ibidem, 26, 28.
} 
TABLE 19 Sentences for common property offences in the criminal bylaws of 1756

\begin{tabular}{|c|c|c|c|}
\hline Category & Condition & Value* & Punishment \\
\hline \multirow[t]{11}{*}{ 'Furto semplice' } & First time & $<10$ & Pillory or Strappado \\
\hline & “ & Oct-5o & Lashing \\
\hline & “ & $5^{0-100}$ & 5 years galleys \\
\hline & “ & $100-300$ & 7 years galleys \\
\hline & “ & $300-500$ & 10 years galleys \\
\hline & “ & $500-1000$ & Life-long galleys \\
\hline & “ & $>1000$ & Death by hanging \\
\hline & Second time & Any & 10 years galleys \\
\hline & Third time & $<20$ & Life-long galleys \\
\hline & “ & $>20$ & Death by hanging \\
\hline & Fourth time & $15^{-20}$ & Death by hanging \\
\hline $\begin{array}{l}\text { 'Furto qualifi- } \\
\text { cato' }\end{array}$ & $\begin{array}{l}\text { Aggravating } \\
\text { circumstances }\end{array}$ & $>10$ & Death \\
\hline \multirow[t]{3}{*}{ Swindle } & First time & $\begin{array}{c}<25,25-500 \\
>500\end{array}$ & $\begin{array}{l}\text { Strappado, Lashing, } \\
\text { Galleys }\end{array}$ \\
\hline & Second/third & Any & 5 years galleys \\
\hline & More times & Any & $\begin{array}{l}10 \text { years to life-long } \\
\text { galleys }\end{array}$ \\
\hline Robbery & $\begin{array}{l}\text { Type of good/ time } \\
\text { of theft }\end{array}$ & & $\begin{array}{l}\text { Life-long galleys to death } \\
\text { by hanging }\end{array}$ \\
\hline $\begin{array}{l}\text { Property } \\
\text { damage }\end{array}$ & $\begin{array}{l}\text { Location/ what is } \\
\text { damaged }\end{array}$ & & $\begin{array}{l}\text { Life-long galleys to death } \\
\text { by hanging }\end{array}$ \\
\hline
\end{tabular}

SOURCE: BANDO GENERALE (1756) 40-62

* Counted in Roman scudi (1 Roman scudo $=5$ Bolognese lire)

Serbelloni's 1756 Bando Generale for the first time explicitly mentions sex as a factor of systematic sentence differentiation. By then, these criminal bylaws no longer distinguished appropriate punishments for men and women in the text about the specific crimes themselves. Instead, they stress in the introductory remarks that the judge is free to impose judgement on women proportional to their sex, commuting punishments like the galleys and public strappado to the more suitable options of confinement, exile or lashing. ${ }^{18}$ Understanding

18 Bando generale Serbelloni 1756, 3-4: "Dichiara, che in tutte, e single disposizione del presente Bando sono comprese le Donne, benchè di esse non se ne veda fatta alcuna espressa 
how and to what extent the penal norms transcended the theoretical realm and were put into practice thus requires further scrutiny of the criminal court records.

\section{Prosecution and Sentencing}

The widespread culture of violence and the use of the criminal court as a forum for conflict resolution meant that acts of aggression rather than property crimes constituted the main reason for an encounter with the law in early modern Bologna. The several hundreds of complaints about property crimes each year made up about one-sixth of the denunciations to the Torrone. Similarly, the average of 80 criminal investigations constituted just over a quarter of the processi (see table 20). ${ }^{19}$ These shares seem rather modest compared to those found in towns in northern Europe, where criminal courts were as a rule far more prone to prosecute theft and other property offences. ${ }^{20}$ However, as has already been discussed, the preponderance of crimes against the person rather than against property before criminal courts seems to have been shared among towns in early modern southern Europe. ${ }^{21}$

Despite constituting a modest portion of the Torrone's judicial dealings, theft and other property offences were considered serious threats to public

menzione, e loggiaceranno alle pene cominate, come se inciascun Capitolo fossero particolarmente nominate, nelli Delitti però a loro convenienti, e possibili a commettersi, e nelle pene altresi proporzionate al lor sesso, mentre rispetto alle pene non convenevoli, come di Galera, Corda in pubblico, e simili, si commuteranno nella Rilegazione, Esiglio, Carcere, Frusta, ed altre ad arbitrio secondo la qualità delle Persone, e circostanze de'fatti."

19 During the period under investigation, the Tribunale del Torrone employed 8 notaries who recorded the denunciations. One of them was the chief-notary who oversaw the others. My samples of the notebooks of one notary per focus year have led me to estimate that the number of denunciations for property crimes must have ranged between 200 and $45^{\circ}$ each year. For an average $45 \%$ of the thefts reported to the Torrone no suspects were identified, for example because the thefts had transpired at night-time or for other reasons had no witnesses. The indicated number of process $i$ here is based on an exhaustive survey of (extant) criminal court investigation dossiers for the five sample years.

20 Noordam, 'Strafrechtspleging en criminaliteit in Delft,' 228; Old Bailey Proceedings Online (www.oldbaileyonline.org, version 7.2, March 2015), Tabulating offence category, between 1674 and 1800 . Counting by defendant; G. Morgan and P. Rushton, Rogues, thieves and the rule of law. The problem of law enforcement in north-east England, 1718-1800 (London: UCL Press, 1998) 6o; Schwerhoff, Historische Kriminalitätsforschung, 116. 
TABLE 20 The share of property offences among denunciations and processi, ca. 1655-1755

\begin{tabular}{lccc}
\hline & $\begin{array}{c}\text { Among } \\
\text { total known offenders }\end{array}$ & $\begin{array}{c}\text { Among } \\
\text { female offenders }\end{array}$ & $\begin{array}{c}\text { Among } \\
\text { male offenders }\end{array}$ \\
\hline Denunciations & $17 \%$ & $11 \%$ & $18 \%$ \\
Processi & $26 \%$ & $39 \%$ & $25 \%$ \\
\hline
\end{tabular}

SOURCES: SAMPLE 1 AND 2A (SEE APPENDIX), COUNTED BY DEFENDANTS

order. The interest in prosecuting property crimes was visible in the harsh sentences prescribed by the criminal bylaws. It was also reflected in the increased importance of property offences among the processi between the mid-seventeenth and mid-eighteenth century. Among the processi 26 per cent of the offenders were accused of property crimes compared to only 17 per cent of the offenders at the level of the denunciations. Some other crimes, such as the petty acts of violence so prevalent among the denunciations, were almost never turned into a formal investigation. This was different for property crimes: the authorities were keen to try to locate and prosecute the offenders even for small-value thefts. ${ }^{22}$ It was not uncommon for a criminal investigation concerning petty theft to be more elaborate and complex than a homicide trial, in some cases involving dozens of testimonies and hundreds of folios. ${ }^{23}$

Property offences made up a significant part of the crimes for which women were subjected to a formal investigation by the judicial magistrates. The importance of this type of offence rose throughout the criminal justice process, which is witnessed by the discrepancy between the proportional share of property crimes among the denunciations and the processi for both men and women. This disparity was nevertheless particularly stark for female defendants. At the level of the denunciations, only 11 per cent of the female offenders were accused of having committed a property crime; far outweighed by complaints about all sorts of violence. Among the processi, however, the share of property offences rose to 39 per cent, making it the most important crime category for women at this level. This was most likely not only due to the perceived seriousness of property crimes. After all, the fact that property offences ranked so highly on the types of crimes for which women were investigated was also contingent on the fact that other offences brought before the Torrone,

22 Angelozzi and Casanova, Donne criminali, 243.

23 Angelozzi and Casanova, La giustizia criminale a Bologna nel XVIII secolo, 143. 
Types of urban property crimes before the Torrone, ca. 1655-1755

\begin{tabular}{|c|c|c|c|c|c|c|c|c|}
\hline & $\begin{array}{l}\text { Theft } \\
\text { (furto) }\end{array}$ & $\begin{array}{l}\text { Swindle } \\
\text { (truffa) }\end{array}$ & $\begin{array}{l}\text { Cutpursing } \\
\text { (crumenari) }\end{array}$ & $\begin{array}{l}\text { Robbery } \\
\text { (rapina) }\end{array}$ & $\begin{array}{c}\text { Property } \\
\text { damage } \\
\text { (danno } \\
\text { dato })\end{array}$ & $\begin{array}{l}\text { Violation of } \\
\text { seizure } \\
\text { (violatione di } \\
\text { sequestro) }\end{array}$ & Misc. & Total \\
\hline $\begin{array}{l}\text { Female offenders } \\
(\mathrm{N}=91)\end{array}$ & $86 \%$ & $6 \%$ & $1 \%$ & $1 \%$ & $3 \%$ & $3 \%$ & - & $100 \%$ \\
\hline $\begin{array}{l}\text { Male offenders } \\
\left(\mathrm{N}=5^{8} 3\right)\end{array}$ & $76 \%$ & $5 \%$ & $1 \%$ & $11 \%$ & $3 \%$ & $1 \%$ & $3 \%$ & $100 \%$ \\
\hline
\end{tabular}

SOURCES: CALCULATIONS BASED ON ALL DENUNCIATIONS AND PROCESSI CONCERNING PROPERTY CRIMES FROM SAMPLES 1, 2A, 2B AND 3 COMBINED (SEE APPENDIX), COUNTED BY DEFENDANTS

such as their violent encounters, were not. The judicial ambiguity that female property offenders faced will be treated more extensively later in this section.

Theft figured prominently among the different property offences committed by men and women. The property crimes that were reported to the Torrone ranged from violation of the terms of seizure, property damage to animals, trees, shops or houses, to robbery, cutpursing or pickpocketing, swindle and theft (table 21). Contemporary classifications of these crimes can be deduced from the criminal court records, and can, amongst others, be gleaned from the top right corner of dossiers' front cover. Following these contemporary categorizations, theft (furto) consists of the successful or attempted theft of goods or animals of values big or small, with or without breaking in, during the day or at night. ${ }^{24}$ This category furthermore includes the receiving of stolen goods, since neither the criminal bylaws nor the processi classifications differentiated between the acts of stealing and receiving. ${ }^{25}$ Theft as such constituted over threequarters of the male and female property offenders that came before the Torrone.

The prosecution of property offences was not solely a matter of top-down control. Victims and other private individuals played key roles in the identification of suspects in the preliminary stages of the criminal process in early modern Europe. ${ }^{26}$ In Bologna the overwhelming majority of theft cases were brought to the court's attention by victims who had noticed missing items

\footnotetext{
24 Bando generale Giustiniano 1610, 26-28; Bando generale Serbelloni 1756, 39-62.

25 Angelozzi and Casanova, Donne criminali, 96; Bando generale Serbelloni 1756, 53-55.

26 C. Herrup, 'New shoes and mutton pies: Investigative responses to theft in seventeenthcentury East Sussex,' The historical journal 27:4 (1984) 817; Rublack, The crimes of women, 28 .
} 
from their domiciles, shops or purses, rather than by public officials or patrolling lawmen. When reporting a theft to one of the criminal court's notaries, a little over half of the victims revealed already having vague or more concrete suspicions about the offender's identity. Court records reveal that accusations were often based on rumours heard in the neighbourhood, and sometimes on a personal investigation. In a case from 1705 , for example, the widow Orsola Borzaghi initially had no knowledge about who had stolen her two dresses, estimated to be worth about 25 lire. After visiting a prison to ask around if anyone there had any information, one of the women incarcerated there pointed her towards the eighteen year-old, unmarried silk weaver Anna Bellisia, whom she ended up denouncing to the Torrone. ${ }^{27}$ Orsola's statement reveals the strategic purpose of her statement: in her denunciation she explains: "Però son comparsa as esporre querela contro chi sarà stato il ladro [...] ad effetto, che sia castigiato et io rifatto del danno" - she had lodged this criminal complaint to have the thief reprimanded and, furthermore, to be reimbursed for the damages. ${ }^{28}$

Despite the clear interest in finding and prosecuting thieves, the casebooks reveal that both authorities and plaintiffs were only able to do so for a limited number of them. Many of the reported thefts did not indicate a possible culprit because break-ins often transpired at night or because thieving for other reasons had no witnesses. This occurred quite frequently: for about 45 per cent of the thefts among the denunciations no suspects were identified. Even following a formal investigation, one-fifth of the theft cases still had no recorded suspect. ${ }^{29}$ The inability to locate such a proportion of the culprits is not likely to have been a specificity of the Bolognese or Italian criminal justice system. More than anything they reveal the range and richness of the judicial administration on the Italian peninsula. Even cases that had little chance of being solved were carefully recorded and archived.

Among the property offenders that were identified and indicted as part of a formal investigation, a little less than half were found guilty. Chances of being banished (esilio) were particularly high (table 22). Even though this type of sentence was undiscussed in the city's criminal bylaws, nearly a quarter of the 393 defendants who were formally investigated for property crimes was sentenced to be banished from the Bolognese territory for an undetermined amount of time. The prevalence of banishment sheds light on its function: as it was commonly used as an instrument to moderate strict laws and often

\footnotetext{
27 ASво, Torrone, $7602-2$, fasc. 26.

28 Ibidem, fol. $1 v$.

29 This was calculated based on the exhaustive sample of processi for the years 1655, 1675, 1705, 1725 and 1755, which include 39 investigations for theft in which no suspect is identified (out of 209 theft cases).
} 
TABLE 22 Registered sentences for property crimes among processi, ca. 1655-1755

\begin{tabular}{lcccc}
\hline & \multicolumn{2}{c}{ Female defendants } & \multicolumn{2}{c}{ Male defendants } \\
\hline Capital punishment & - & - & - & - \\
Banishment & 10 & $24 \%$ & 78 & $31 \%$ \\
Galleys & - & - & 21 & $8 \%$ \\
Incarceration & 4 & $10 \%$ & 11 & $4 \%$ \\
Corporal punishment & - & - & 1 & $0 \%$ \\
Fine & - & - & 4 & $2 \%$ \\
Pardon & 5 & $12 \%$ & 17 & $7 \%$ \\
Surety/precetto & 6 & $14 \%$ & 48 & $19 \%$ \\
Cancelled/absolved & 17 & $40 \%$ & 72 & $29 \%$ \\
Total outcome known & 42 & $100 \%$ & 252 & $100 \%$ \\
Outcome unknown & 16 & & 83 & \\
\hline
\end{tabular}

SOURCE: COMBINATION OF THE PROCESSI FROM SAMPLE 1 AND ADDITIONAL PROCESSI INVOLVING FEMALE OFFENDERS FROM SAMPLE 3 (SEE APPENDIX)

replaced capital punishments or a sentence to the galleys. ${ }^{30}$ Some scholars have argued that capital punishments were most commonly prescribed for property offences. Based on the registers of people that were sentenced to death in early modern Bologna, it has been shown that more defendants were sentenced to death for property offences than for any other type of crime. ${ }^{31}$ The Bolognese casebooks reveal that capital punishments for thefts and other property offences were nevertheless fairly uncommon between the mid-seventeenth and mid-eighteenth centuries. Other punitive and reconciliatory measures were preferred.

In early modern Italy there was a strong connection between banishment, reconciliation and pardon. Elsewhere in Europe it was common to make a distinction between lifelong banishments - which entailed the loss of all civil rights and the confiscation of possessions - and temporary banishments from the town, region, province or country for periods of 1 to 5 o years. ${ }^{32}$ In Bologna the convicted generally suffered exile from the entire legal territory for

$30 \quad$ Nubola, 'Giustizia, perdono, oblio,' 14; Tedoldi, La spade e la bilancia, 144, 152.

31 Angelozzi and Casanova, Donne criminali, 244.

32 A. Schmidt and J.M. Kamp, 'Excluding the unwanted? Banishment in early modern cities: Frankfurt am Main and Leiden in the 17th and 18th centuries' (Unpublished conference paper, Urban History Conference 2016). 
indeterminate periods of time, until he or she was able to make peace with the victim or the victim's family. After a peace accord had been achieved, offenders could request a pardon for their crimes. Although not systematically recorded by the extant criminal court records, most of the pardoned Bolognese property offenders had initially received a banishment sentence. The pardon rates for property crimes were significantly lower than for crimes such as homicide: while nearly 40 per cent of the recorded killers were pardoned, less than 10 per cent of the property offenders could count on one. Nevertheless, the culture of reconciliation played a significant role in how inhabitants and magistrates dealt with property offences in early modern Bologna.

The importance of peacemaking procedures is also apparent in the cancellations of processi. Over one-fifth of the formal investigations for property offences by the Torrone were halted. Reasons for halting an investigation could be the lack of evidence, because the defendant was considered innocent, or because a settlement had been reached between the plaintiff and the defendant. At least half of the cancellations stemmed from a withdrawal of the complaint by the plaintiff (rinuncia), which generally meant that a peace accord or another kind of agreement had been achieved, often involving some form of compensation. ${ }^{33}$ In this respect too, the proportion of cases that were cancelled is lower than for acts of violence, but is nevertheless indicative of the pervasiveness of the culture of peacemaking in the criminal justice system. ${ }^{34}$

While reconciliation played an important part in the judicial dealings of both male and female offenders, some salient gender differences in sentencing can be discerned. A few 'typical' differences apparent from the Bolognese sources have also been observed for other early modern towns. ${ }^{35} \mathrm{~A}$ sentence to man the oars of the papal galleys, for example, was reserved for male offenders. Female property offenders, on the other hand, appear to have been somewhat more likely to be incarcerated than their male counterparts. Ideas about the gendered suitability of certain punishments, also reflected in the criminal bylaws, arguably played a role in shaping these patterns. The tendency towards locking away women should also be viewed within the context of the early proliferation of institutions for 'problematic' women and girls in Italy following the Counter-Reformation. ${ }^{36}$ Fearing their potential poverty-driven immorality,

33 Niccoli, 'Rinuncia, pace, perdono,' 224.

34 Sara Cucini also observed that theft cases were less frequently halted than those for violence, see S. Cucini, 'Législation statutaire et gouvernement pontifical en Italie centrale. Le cas de l'administration de la justice criminelle à Bologna, deuxième moitié du Xve siècle' (Unpublished PhD thesis, Université Paul-Valéry, 2014) 359.

35 King, Crime and law in England, 170.

36 Cohen, The evolution of women's asylums since 1500, 3, 8; Terpstra, Cultures of charity, 17. 
a continuum of correctional and charitable institutions - unprecedented in number and scope - sought to help, supervise and correct women in various stages of their lives. The case against the single domestic servant Maria Cantelli illustrates a cycle of care and control from which she could not escape. ${ }^{37}$ She was sent out from the workhouse (the Mendicanti) where she was residing to work as a domestic servant in a noble house. When her employer wanted her to return to the work house after eight days, Maria fled with some of her employer's clothing and pearls worth 15 filippi. Upon her capture she stated she had resorted to the theft because she had dreaded returning to the workhouse, "where the circumstances and people were so bad." Despite her plea, she was transported back to the Mendicanti not long after.

Although the sentences that male and female offenders received were not drastically different, there are important signs that women's involvement in property crimes was not always taken as seriously as men's. Overall, women made up 14 per cent of the accused property offenders among the denunciations, but only a little over half that (7.7 per cent) at the level of the processi. Female offenders' 'vanishing' from the criminal justice process can at least in part be attributed to the considerable degree of indulgence in the treatment of female property offenders observable in the criminal court dossiers. Female offenders were often absolved before even being formally interrogated if they had one or more male co-offenders in other types of crimes - especially in the case of theft. ${ }^{38}$ Angelozzi and Casanova justly remarked that this indulgent 'chivalry' should not be viewed as a display of favour, but rather as paternalism rooted in ideas of women's minority and subordination in every social sphere. ${ }^{39}$ Women's involvement was thus often considered irrelevant, regardless of their role in the crime.

That women with male co-offenders might receive little scrutiny from the criminal court for their roles in property crimes becomes apparent from a case that deals with the theft from Elena Leni. ${ }^{40}$ She complained to the criminal court that clothing and jewellery worth around 300 scudi (or 1500 lire) had been stolen from her house, accusing her husband Pietro Maria Gentili as well as her two tenants: the married couple Marco Antonio and Camilla Alberti. Both the husband and the male tenant were arrested by the criminal court's lawmen, were held in prison for twelve days and were tortured for a confession through the corda. Despite the contradictions in their stories, they insisted on

AsBo, Torrone, 7859-2, fasc. 51, especially fol. $13 \mathrm{r}$ and $16 \mathrm{r}$.

38 Angelozzi and Casanova, Donne criminali, 239, 242.

39 Ibidem; Casanova, 'Crimini di donne, giudici benevoli,' 1.

40 Asвo, Torrone, 5674, fol. 301r-352v, 570r-589v, as discussed in Angelozzi and Casanova, Donne criminali, 244-246. 
their innocence and the two men were liberated into exile until they were able to receive a pardon several months later. Camilla, however, did not only escape torture but was furthermore released after only a short initial interrogation, despite the fact that all of the evidence seemed to point as much as to her as to the two men. That the role of Camilla in this theft - as a young woman in the presence of men - was so readily dismissed is certainly telling of the attitude of the magistrates in the criminal process.

Although property offences were considered grave crimes in early modern Bologna, judicial practice diverged significantly from the letter of the law. The specific functioning of the legal system across the Italian peninsula played an important role in bringing about this disparity. The legal culture that accepted and stimulated peacemaking efforts so prevalent among cases of violence was also apparent among the judicial dealings of property offences, in spite of the importance attached to prosecuting these types of crimes. The prosecution of property offences was furthermore contingent on gender expectations and gendered notions of responsibility, culpability and judicial relevance. As we have seen, this affected not only how property offences were punished but also the extent to which the authorities considered women to be criminal actors in the first place.

Property offences nevertheless constituted the most important crime category for which women were investigated by the criminal court. If and to what extent the circumstances and characteristics of their crimes were gendered therefore deserves further scrutiny. Because of its importance among property offences dealt with by the Torrone during the mid-seventeenth and mid-eighteenth centuries, it will be thefts and the related activities of receiving and reselling stolen goods that take centre stage in this examination.

\section{The Social Profile of Thieves and Economies of Makeshift}

Economic conditions and experiences of poverty have played important roles in the scholarly thinking about the contexts of property crimes. The increasing economic deterioration has figured prominently in the scholarship about antico regime Italy. A prevailing idea since the $1950 \mathrm{os}$ has been that Italy became increasingly poor throughout the sixteenth and seventeenth centuries as economic leadership shifted from the Mediterranean to the northwest Atlantic. ${ }^{41}$ In his work from the late 1980s, Stuart Woolf surmised that this pauperism in

41 For an overview, see A. Cavaterra, 'Economia, povertà e consumi in età moderna,' in B. Coccia (ed.), La quarta settimana: Storia dei bisogni e dei consumi degli italiani che oggi 
Italy was reflected in the decline of urban employment, falling levels of consumption, the organisation of institutional charity and the growing exploitation of female and child labour. ${ }^{42}$ However, more recent works have argued for regional differentiation and have furthermore shifted this caesura to the eighteenth century. Large cities like Venice lost out in sea transport during the seventeenth century, though towns like Bologna endured only relatively mild decline - at least until the mid-eighteenth century, when living standards worsened drastically in Italy due to the decline of real wages and a significant increase of price levels. ${ }^{43}$ While the real economic crisis was still to come, Bologna's stagnating textile industry undoubtedly impacted the lives of many underemployed and underpaid inhabitants relying on textile work to make ends meet throughout the seventeenth and eighteenth centuries.

As far as the Bolognese criminal court was concerned, the problem of pauperism was predominantly one of men. Particularly after $175^{\circ}$ pickpocketing and small-value thefts as well as cases against male beggars and vagabonds deprived of any credible means of subsistence surged among the Torrone's casebooks; a result both of deteriorating economic conditions and of biased policing. ${ }^{44}$ For female offenders there is no evidence for such an increase in property crimes, vagabonding or begging. Concerning property crimes, Angelozzi and Casanova found 30 female offenders in their sample of processi and denunciations from 1671 compared to only 16 in 1775-1779 (constituting 8.6 per cent of all recorded female offenders versus 13.6 per cent in 1671$).{ }^{45}$ In the face of hardship the Torrone increasingly dealt with certain criminalized deeds of men, but largely neglected to do so for women. The tendency in Italy since the Renaissance to institutionalise rather than criminalize women as an answer to the threat of their poverty-driven sexual immorality, may provide a partial explanation for this difference.

The relationship between poverty and theft prosecutions is not only inconclusive for women in Bologna, but has been debated in early modern European historiography more broadly. Most historians tend to accept that theft was a key survival strategy employed by the poor in times of need, and that

non arrivano alla fine del mese (Rome: Editrice APES, 2009) 15-25; Malanima, 'Urbanisation and the Italian economy,' 97-98; Black, Early modern Italy, 32-35.

42 Woolf, The poor in Western Europe, 51-53.

43 Black, Early modern Italy, 35; Guenzi, 'L'identità industriale,' 449; P. Malanima, 'An age of decline. Product and income in eighteenth-nineteenth century Italy,' Rivista di storia economica 12:1 (2006) 111; P. Malanima, 'I consumi in età moderna. Crescita o decline?,' in E. Sori and R. Giulianelli (eds.), Consumi e dinamiche economiche in età moderna e contemporanea (Napels: ESI, 2011) 44.

44 Angelozzi and Casanova, Donne criminali, 71.

45 See table 2 in Angelozzi and Casanova, Donne criminali, 73. 
fluctuations in property crimes were tied to economic conditions in one way or another. ${ }^{46}$ Three factors are deemed particularly important: the prices of necessities, especially food, and the availability and remuneration of work. The results from statistical analyses linking indictments for property offences to price indexes in early modern Europe nevertheless provide unclear results. Beattie found "a general relationship" between these variables for the late eighteenth-century rural parishes of Surrey and Sussex, but found that the situation for London was more complex. ${ }^{47}$ Neither the massive peaks in indictments for property crimes, nor the long-term trends in the city of London seem to have been related to the development of prices. Similarly, German historians have also found no or only marginal evidence for a correlation between rye or bread prices and property offences in sixteenth-century Cologne and eighteenth-century Frankfurt. ${ }^{48}$

The difficulty of finding quantitative evidence for the link between economic hardship and theft has recently been confirmed by Kilday. In her statistical analysis of eighteenth-century rural Oxfordshire she set off the variables of wages, prices and weather conditions against the indictment levels for theft to demonstrate that the correlations were rather weak. This suggests that while temporary poverty may have been a motivating factor for some to steal, "motives for theft may well have been more closely related to opportunism and acquisitiveness." ${ }^{49}$ Similar conclusions have recently been drawn for towns in early modern Holland, which also endured crisis in various economic segments during the second half of the eighteenth century. ${ }^{50}$ While the share of property offences rose in some towns, in others such as Leiden (which, like Bologna, endured a significant textile crisis) it did not.

The influence of economic fluctuations on criminal activity was thus noticeable but not straightforward. Bologna's seventeenth-century criminal records also attest to this. In the period from 1625 to 1629 a temporary increase in thefts committed by women can be observed, which could be explained by the grain shortage and the rise in bread prices in the city at that time. ${ }^{51}$ In these crisis years, thefts constituted far higher shares of reported crimes than in the

46 Beattie, “The criminality of women,' 103; A.M. Kilday, “'Criminally poor?” Investigating the link between crime and poverty in eighteenth century England,' Cultural and social history: The journal of the Social History Society 11:4 (2015) 507. J.M. Beattie, 'The pattern of crime in England 166o-180o,' Past \& present 62 (1974) 91

48 Schwerhoff, Köln im Kreuzverhör, 358-361; Eibach, Frankfurter Verhöre, 93-99.

49 Kilday, “'Criminally poor?," 521.

$5^{\circ} \quad$ Van der Heijden, Women and crime, 74-75.

$51 \quad$ Angelozzi and Casanova, Donne criminali, 96. 
sampled years before and afterwards. ${ }^{52}$ However, for other periods with similar crises this connection is less apparent. When another increase in bread prices in 1671 provoked riots and attacks on bakeries in the city of Bologna, the Torrone's records provide no evidence for any proportional or absolute increase in the reported thefts by women. ${ }^{53}$

When the effects of economic fluctuations on property crime are discussed, scholars generally agree that the context of theft in the early modern period was one of large parts of the population living a hand-to-mouth existence. For this they commonly draw on Olwen Hufton's concept of the 'economy of makeshifts. ${ }^{54}$ Originally devised to summarise the eighteenth-century French experience of marginality, this concept refers to the wide range of disparate activities and survival strategies that poor commoners employed to support themselves in the face of economic hardship. Initially these makeshifts only included economic activities such as subsistence migration, begging and gleaning, which complemented often temporary and poorly paid jobs. As the concept was adopted by others, 'making shift' came to include the numerous and often combined short-term strategies and local resources that ensured the survival of individuals and families, including formal and informal relief as well as various types of marginal criminality such as prostitution and petty theft. ${ }^{55}$

The overarching notion of makeshift economies is also useful to contextualise the situation in early modern Bologna. Here, as elsewhere in Europe, a combination of need, greed and opportunity occasionally drove its inhabitants to steal in their attempts to make shift. ${ }^{56}$ While the criminal bylaws expressed worry about the repeatability of theft and its effects on public order, only few professional thieves seem to have passed through the Italian criminal courts

$5^{2} \quad$ In their samples of denunciations and processi taken together, thefts constituted $6.6 \%$ of women's crimes in 1583-1587 and 13.6 per cent in 1671 . See Angelozzi and Casanova, Donne criminali, 73 .

53 L. Ferrante, “Tumulto di più persone per causa del calo del pane..." Saccheggi e repressione a Bologna (1671, 1677),' Rivista storica italiana 9o (1978) 770-809.

54 O. Hufton, The poor in eighteenth-century France, 1750-1789 (New York: Oxford University Press 1974) 259.

55 For an overview of the evolution of Olwen Hufton's concept of the economy of makeshift, see A. Tomkins and S. King, 'Introduction,' in S. King and A. Tomkins (eds.), The poor in England 1700-1850. An economy of makeshifts (Manchester: Manchester University Press, 2003) 12-13.

56 Brackett, Criminal justice and crime, 118; P. Wettmann-Jungblut, "Stelen inn rechter hungersnodtt." Diebstahl, Eigentumsschutz und strafrechtliche Kontrolle im vorindustriellen Baden 160o-185o,' in R. van Dülmen (ed.), Verbrechen, Strafen und soziale Kontrolle. Studien zur historischen Kulturforschung (Frankfurt am Main: Fischer Taschenbuch Verlag, 1990) 154-155. 
before the nineteenth century. ${ }^{57}$ The Bolognese criminal court records only make occasional references to defendants being repeat offenders or ladrifamosi (famous thieves). Among over more than one hundred identified offenders of theft in the formal investigation dossiers, only 14 were recorded as having a criminal history. ${ }^{58}$ Since recidivism was an aggravating factor in sentencing, it does not seem very likely that the people whose criminal past was unrecorded in the criminal court dossiers were known to be repeat offenders.

The Bolognese sources furthermore provide little evidence for the incorporation of thieves into larger criminal associations. When stolen wares were sold on, the criminal court actively tried to establish who was involved in the distribution of the stolen goods and whether intermediaries were accomplices in the crime or had acted in good faith. ${ }^{59}$ Nevertheless, while the small percentage of armed robbers commonly offended in small groups, the Torrone's criminal court records suggest that the large majority of thieves operated independently. In three-quarters of the recorded thefts only one offender was accused. ${ }^{60}$ This was the same for male as for female defendants and has also been observed for sixteenth-century Rome. ${ }^{61}$ In the quarter of the cases where the Torrone did identify co-offenders, women were more likely to commit thefts in mixed-sex groups (mostly with their husbands or other male family members) than in groups with only other women. The opposite is true for men, who more commonly offended in all-male groups. The Bolognese pattern in which women and men largely committed thefts on their own corresponds with what has been observed for other towns in early modern Europe. ${ }^{62} \mathrm{~A}$ lack of an expansive apparatus of criminal justice and policing undoubtedly contributed to shaping this pattern. Nevertheless, the criminal court records attest to the role

57 J.K. Brackett, 'The Florentine criminal underworld. The underside of the Renaissance,' in W.J. Connell (ed.), Society and individual in Renaissance Florence (Berkeley: University of California Press, 2002) 301, 308; L. Lacché, Latrocinium. Giustizia, scienza penale e repression del banditismo in antico regime (Milan: Giuffrè Editore, 1988); Angelozzi and Casanova, Donne criminali, 94, 96; Dean, Crime and justice in late medieval Italy, 186.

$5^{8}$ In the entire extended sample of all crimes in Bologna (samples 2 and 3 , see appendix 1 ) only 16 men and 4 women were described as having previously been in contact with the law for a criminal offence. However, the written court records do not provide systematic information on all offenders, even for those officially indicted by the criminal court and/ or incarcerated for questioning. Among the 108 offenders of theft in the processi alone, 28 were investigated regarding their previous criminal activities; 14 of them were recidivists. Angelozzi and Casanova, Donne criminali, 96; Bando generale Serbelloni 1756, 53-55.

6o The thefts for which no offender was identified are excluded in this calculation.

61 Blastenbrei, Kriminalität in Rom, 193 .

62 Van der Heijden, Women and crime, 75-76. 
of predominantly unorganised and occasional theft as one of the many shortterm strategies used by commoners to get by.

The most important characteristic of property offenders throughout the mid-seventeenth and mid-eighteenth centuries is that they had some sort of occupation, however menial. Although unemployment appears to have been more common among defendants accused of thieving than for other crimes, the role of the truly destitute beggars was limited: out of over a hundred property offenders whose occupational status was recorded, only four were described as poor beggars going around the city asking for money and food. Scholars have referred to this kind of group as the structural poor, i.e. those incapable of earning a living for reasons of age, mortal illness or physical handicap and hence fully dependent on assistance or begging. ${ }^{63}$ There are contemporary estimations of Bologna's urban poor for the year 1639, which suggest that a little over two per cent of the Bolognese inhabitants belonged to the category of beggars (mendicanti, poveri che cercano per la città). ${ }^{64}$ In 1726 , they constituted just under three per cent of the urban population. ${ }^{65}$ This means that the share of beggars before the criminal court was roughly equal to their share among the urban population.

A large share of thieves brought before the Torrone probably belonged to the large group of the conjunctural poor: inhabitants that were dependent on low wages or casual employment, but could also include artisans, small retailers and petty officials. ${ }^{66}$ They all found themselves in a fragile equilibrium, could fall easily and repeatedly beneath subsistence level and experienced cyclical poverty. Italian and French case studies have shown that the proportion of the urban poor could include as many as 50 to 70 per cent of all households. ${ }^{67}$ Contemporary estimations of Bologna's urban poor for the year 1639 surmised that the group receiving charitable assistance during Easter and Christmas consisted of over half of the urban population. ${ }^{68}$ As the repercussions of the shrinking

63 Black, Early modern Italy, 105, Woolf, The poor in Western Europe, 6.

64 L. Ciammitti, 'Fanciulle, monache, madre. Povertà femminile e previdenza a Bologna nei secoli XVI-XVIII,' in Arte e Pietà: I patrimoni culturali delle Opere Pie (Bologna: Clueb, 1980) 448 .

65 F. Giusberti, 'La città assistenziale. Riflessioni su un sistema piramidale,' in M. Fanti (ed.), Forme e soggetti dell'intervento assistenziale in una città di antico regime. Atti del IV colloquio, Volume II (Bologna: Istituto per la storia di Bologna, 1984) 23.

66 Black, Early modern Italy, 105; Woolf, The poor in Western Europe, 6.

67 Woolf, The poor in Western Europe, 6.

68 For this calculation I have used Ciammitti et al's data for 1693 and compared them to the 1,701 estimates of the total urban population provided by Bellettini, which was the nearest in time. Compare Ciammitti, 'Fanciulle, monache, madre', 448; Bellettini, La popolazione di Bologna, 48. 
textile sector and consequent reforms of the production process were felt increasingly by the many textile workers in Bologna, it is unlikely that this share of the working poor diminished during the subsequent period. ${ }^{69}$

The occupations of those accused of theft in the Bolognese criminal records represent a broad dissection of predominantly lower-class society. Defendants of both sexes indicate performing a wide range of professions for their livelihoods, albeit on-and-off or underemployed. Some of the accused held esteemed occupations such as civil notaries or worked as skilled master artisans and shopkeepers, but most of those involved in theft belonged to the city's large group of textile workers, cobblers, bricklayers, porters, servants, and market vendors. The court records shed some light on the precarious nature of their employment and the role of theft in easing economic burdens. In August 1674 Giovanni Biaccati had stolen two rings and gold earrings worth 21 lire from his neighbour's unlocked trunk when he was in her house listening to a violinist playing on the street opposite to her apartment. ${ }^{70}$ Giovanni, who had fled the city together with his wife after the theft, was described as a woodworker, yet the testimony by the culprit's former boss underlines how the irregularity of work drove artisans like Giovanni to other forms of employment. When times were tough and there was no work to be found in his profession as a woodworker, Giovanni had to compete for unstable and ill-paid porter jobs to try and make ends meet. Examples such as these clearly illustrate the role of underemployment and cyclical hardship in the lives of early modern bolognesi and the lure of the temporary alleviation theft could provide.

The women featured in the Bolognese criminal court records for their misdeeds were no better off socioeconomically. Female offenders worked as market vendors, domestic servants, or performed odd jobs. A significant share of these women were active in the textile industry in the less prestigious and poorly paid functions of spinners, weavers, hosiers, and seamstresses who relied on the uncertainties of piecework and the capricious supply of work through a kind of putting-out system headed by merchant contractors. ${ }^{71}$ Catarina Benserati, the aforementioned widow who stole salted pork from her neighbours, for example, described herself as a woman "living how god wanted her to through spinning and some charity bestowed upon her by her neighbours." ${ }^{72}$ She was only one example of the broad category of the working

69 Guenzi, 'Lidentità industriale,' 449, 470-472, 5 O7.

7 А Азво, Torrone, $7028-2$, fasc. 7 .

71 Terpstra, 'Working the cocoon,' 48-49; Dumont, 'Women and guilds in Bologna,' 7, 9; Guenzi, 'La tessitura femminile,' 250

72 "Io sono una povera donne vecchia che vivo come iddio vuole con filare e con qualche carità che mi viene fatta dalli vicini," АSBo, Torrone, 8179-2, fasc. 16 . Also see 6620, fol. 285 . 
poor who lived just above or on subsistence level and attempted to maintain a livelihood through the household's combined labour efforts, occasional charity and, for some, opportunistic theft.

There are some indications that married locals were prominent among Bologna's thieves. The criminal court records suggest that where marital status was registered, over two-thirds of the property offenders were married. Furthermore, fewer than one in seven of the accused property offenders were recorded as being from outside of the Bolognese legato and thus as foreigners. These findings go against the dominant historiographical grain that stresses an important link between high mobility, economic vulnerability and theft. In his well-known contribution on women's criminality in eighteenth-century Surrey, John Beattie contrasted the socioeconomic profile of thieving women to those who came before the court for violence. While most of the women accused of crimes against the person were married, prosecutions for theft revolved around single and widowed women. ${ }^{73}$ Similarly, in his examination of the social background of female property offenders in late eighteenth-century London, Peter King found that over two-thirds of them were single or widowed and over half of them were born outside the metropolis. ${ }^{74}$ Scholarship on early modern towns in Holland and in Frankfurt am Main has painted a similar picture of young female migrant thieves. ${ }^{75}$

The social profile emerging from the Bolognese criminal court records may in part be due to the character of the source material. During the early modern period, the recording of biographical data such as marital status and birth place in the judicial sources increased and was progressively standardised, but was still patchy at best by the mid-eighteenth century. ${ }^{76}$ Especially incomplete was the information on the marital status for men, as it was only recorded for about one-fifth of the male property offenders. Furthermore, although over half of the court records shed light on the birth place of the defendants, the interpretation is ambiguous. While the majority of property offenders were recorded as being 'Bolognese' (Bononien), it is not entirely clear whether this only referred to Bologna's urban centre or to the entire legal territory of the legato, which included a vast terrain of 4,00o square kilometres of its suburban

\footnotetext{
73 Beattie, 'The criminality of women,' 101-102, 106-107.

74 P. King, 'Female offenders, work and life-cycle change in late-eighteenth-century London,' Continuity and change 11:1 (1996) 69, 72, 75 .

75 Van der Heijden, Women and crime, 74; Kamp, 'Female crime and household control,' 538.

${ }_{76} \quad$ For female defendants, $57 \%$ of the cases include her marital status and $50 \%$ a birth place. For male defendants, this was $22 \%$ (for marital status) and $58 \%$ (for birth place).
} 
and rural counterparts. ${ }^{77}$ According to Matteo Troila, Bologna's endemic urban population deficit was mainly replenished by the inhabitants from its suburbs, an agricultural zone of between five and twelve kilometres adjacent to the city walls. ${ }^{78}$ More research is necessary to demonstrate whether or not these men and women who were born outside the city were also legally considered migrants by the Torrone, as they would have been in many other European towns.

While caution must be exercised in interpreting the imperfect source material, the demographic, social and economic context of Bologna can serve to at least in part account for the social profile of thieves. First, pertaining to the suggested 'localness' of Bolognese property offenders in particular, various studies have asserted that in communities characterised by low migration theft was naturally more commonly committed by non-migrants. ${ }^{79}$ For rural Tuscany, Brackett contended that theft was linked to a "common misery of a peasantry that always lived on the edge of survival." ${ }^{\prime \prime 0}$ The same has been argued for the eighteenth-century Sénéchaussée of Libourne in France, where three quarters of reported thefts involved "the more stable members of local society."81 In the small textile town of Prato, the large majority of criminal defendants in the eighteenth century also consisted of locals who were by and large born in the city. ${ }^{82}$ Bologa was an important centre of trade and transit, and had large numbers of itinerant travellers spending limited time in the city. ${ }^{83}$ Still, as a middle to large city that did not belong to the important pull areas for temporary migration or agricultural mobility on the Italian peninsula, it does not seem incongruous that Bologna's thieves largely came from the local population. ${ }^{84}$

77 For fifteenth-century Bologna, Sara Cucini observed a relatively fair split between citizens $(32 \%)$ and those being born in the contado $(37 \%)$ among criminal offenders. 'Only' $21 \%$ of the offenders were foreigners (and the provenance of $10 \%$ was unknown). See Cucini, 'Législation statutaire et gouvernement pontifical', 369 .

78 M. Troilo, 'Popolazione e proprietà attraverso le fonti fiscali bolognesi nell'età moderna,' Popolazione e storia 12:1 (2011) 25 .

79 Kilday, 'Criminally poor?', 513

$80 \quad$ Brackett, “'Criminally poor?,' 100.

81 Ruff, Crime, justice and public order, 122.

82 Zuliani, 'Reati e pene nel vicariato di Prato,' 312.

83 Rose, A renaissance of violence, 9 .

84 According to Alberto Guenzi, immigration to Bologna, especially to the city, was very modest in the fifteenth century, rarely exceeding 1,0oo per year. See A. Guenzi, 'Limmigrazione urbana e rurale a Bologna in una fonte del secolo xv,' Rassegna degli Archivi di Stato 44 (1984) 149-163; M. Sanfilippo, 'Il fenomeno migratorio italiano: storia e storiografia,' in A. Miranda and A. Signorelli (eds.), Pensare e ripensare le migrazioni (Palermo: Sellerio, 2011) 245-272; J. Lucassen, Migrant labour in Europe 1600-19oo (London: Croom Helm, 1987) 259. 
Economic characteristics of towns also contributed to a particular social composition of the men and women who appeared before the criminal court. Reflecting on the discrepancy between London's higher and Newcastle's lower shares of single female property offenders, Gwenda Morgan and Peter Rushton hypothesised that the difference may have been related to the distinctive economic life of Newcastle. ${ }^{85}$ They suggest that the slow growth of the town and the character of (largely seasonal) employment possibly drove more impoverished married women towards crime. However, that criminal courts in various early modern European towns with similar economic structures and circumstances were preoccupied by an apparently different population of thieves, suggests that other factors than purely economic ones were probably more decisive.

One of these other relevant factors was the extrajudicial or informal control exerted by households. It is widely accepted that women's crimes all over early modern Europe were more likely to be handled by less formal methods of conflict resolution than men's. ${ }^{86}$ Certain categories of women, such as the generally single domestic servants, are believed to have been extra prone to underreporting as their crimes were probably dealt with within the sphere of the household. ${ }^{87}$ Italy was probably no different, particularly because the paterfamilias had considerable legal room to manoeuvre in exercising control over his wife, children and servants. ${ }^{88}$ When thirteen year old ribbonmaker Flaminia Ruggi had stolen a golden ring from Lucia de Zannoni's house, Lucia first approached Flaminia's parents, who promised to find out the truth. ${ }^{89} \mathrm{After}$ a few days they knocked on Lucia's door to confirm that Flaminia had meanwhile confessed to the theft, and begged her for patience so that they could try to retrieve the ring without interference of the court, and punish Flaminia themselves. While Lucia still denounced Flaminia, this example nevertheless is suggestive of the commonness of extrajudicial negotiations to shield errant family members out of the hands of criminal justice. Unmarried women may have been prime candidates for a special treatment. The importance attached to women's sexual honour in early modern Italy was above all channelled into households' and institutions' attempts to scrutinise and control

85 Morgan and Rushton, Rogues, thieves and the rule of law, 101-102.

86 Schwerhoff, Köln im Kreuzverhör; Shoemaker, Prosecution and punishment, 292; King, Crime and the law, 202-10; Gray, Crime, Prosecutions and social relations, 9, 170-1; Dinges, 'The uses of justice,' $159-75$.

87 Beattie, 'The criminality of women,' 94; Kamp, 'Female crime and household control,' 543.

88 Cavina, Nozze di sangue, 25; Arru, 'The distinguishing features of domestic service in Italy,' 556; Sbriccoli, 'Deterior est condicio foeminarum,' 83-84.

89 АSво, Torrone, 7028 , fol. 54 . 
the movements of single women. ${ }^{90}$ The ability of married women to move somewhat more freely through Italian cities than their single counterparts may have exposed them to more opportunities for theft.

Although the socioeconomic characterisations leave much room for further thought, most of Bologna's thieves appear to have belonged to the large group of the city's working poor. Their often ill-paid and irregular labour activities were merely complemented by theft, if the opportunity presented itself, as part of their economy of makeshifts. ${ }^{91}$ In this sense, the situation in Bologna reminds us of accounts of other early modern towns. It was furthermore largely comparable for male and female property offenders. The next paragraphs will explore the relationship between thieving, the physical and social urban landscape and dynamics of gender in more detail.

\section{$4 \quad$ Stolen Goods}

In the early modern period as much as nowadays, what goods were stolen depended on which goods were at hand. Historians have wondered whether the growing market for consumer goods during the early modern period affected patterns of theft. Scholars such as Beverly Lemire have explicitly stressed the link between the criminal targeting of certain goods, particularly clothing, and the burgeoning popular yearning for new luxury goods and fashionable items. ${ }^{92}$ In Italy, already from eleventh century onwards, the globalisation of trade networks brought in new material goods such as gems, ceramics, cottons, brocades and Turkish carpets. ${ }^{93}$ The indulgence in these material objects by Italy's elite led Richard Goldtwaithe to famously argue that the consumer society was therefore born not in northern Europe in the seventeenth and eighteenth centuries, but in Renaissance Italy. ${ }^{94}$ Other scholars have questioned the extent to

9o Palazzi, ‘Tessitrici, serve, treccole,' 374.

$91 \quad$ For a recap of criminological theories about the role of employment as either facilitating or halting property crimes, see B. Gallée and J. Ligthart, 'De remmende werking van huwelijk en arbeid op vermogensdelicten. Rotterdam, 1812-1820,' Tijdschrift voor criminologie 57:4 (2015) 353-367.

92 B. Lemire, 'The theft of clothes and popular consumerism in early modern England,' Journal of social history 24:2 (1990) 255

93 J.M. Ferraro, 'The manufacture and movement of goods,' in J. Jeffries Martin (ed.), The Renaissance world (New York: Routledge, 2007) 88; A. Clemente, 'Storiografie di confine? Consumo di beni durevoli e cultura del consumo nel xviII secolo,' Società e storia 109 (2005) 591

94 R. Goldtwaithe, Wealth and demand for art in Italy, 1300-1600 (Baltimore: Johns Hopkins University Press, 1993) 16. 
which this consumer culture of Renaissance Italy was able to spread to nonelite segments of the population, if it was sustained throughout the early modern period and furthermore whether this prefigured the developments in eighteenth-century London or Paris. ${ }^{95}$ After all, most forms of retailing remained remarkably stable in Italy and the growth of a mass market remained absent. Combined with declining wages and increasing price levels, Italy's early modern period is generally discussed not as the seed-bed of 'modern consumer culture' but from the perspective of economic decline. ${ }^{96}$

Nevertheless, scholars have convincingly demonstrated that the structure of consumption in Italy did change significantly throughout the early modern period. The available data suggest that a considerable drop in the consumption of foodstuffs coincided with a significant rise in that of durable goods. ${ }^{97}$ Alongside economic indicators, important evidence for a widening demand for consumer goods is derived from probate inventories. Research on these sources reveals an expansion in the number and types of objects held by households across the social spectrum, both in cities in Italy and in the countryside. ${ }^{98}$ Furthermore, the rise of a 'fashion system' increased the demand for certain types of clothing and new accessories such as neckerchiefs. ${ }^{99}$ Despite the economic decline, the mercer trade in Venice, for example, underwent spectacular growth during the seventeenth century. ${ }^{100}$ Moreover, the second-hand clothing

95 E. Welch, Shopping in the Renaissance. Consumer cultures in Italy 1400-1600 (New Haven: Yale University Press, 2005) 4-5, 14; Ferraro, 'The manufacture and movement of goods,' 96; Clemente, 'Storiografie di confine,' $590-592$.

96 For an overview, see Cavaterra, 'Economia, povertà e consumi in età moderna,' 15-25; Malanima, 'Urbanisation and the Italian economy,' 97-98; Black, Early modern Italy, 32-35. P. Malanima and V. Pinchera, 'A puzzling relationship. Consumptions and incomes in early modern Europe,' Histoire \& mesure 27:2 (2012) 198; Malanima, 'I consumi in età moderna,' 67.

98 P. Hohti, "Conspicuous' consumption and popular consumers: Material culture and social status in sixteenth-century Siena,' Renaissance studies 24:5 (2010) 66o; Malanima and Pinchera, 'A puzzling relationship,' 214; R. Ago, Gusto for things. A history of objects in seventeenth-century Rome (Chicago: University of Chicago Press, 2013) 7, 127.

99 C.M. Belfanti and F. Giusberti, 'Clothing and social inequality in early modern Europe: introductory remarks,' Continuity and change 15:3 (2000) 361-362.

100 P. Allerston, 'Meeting demand: Retailing strategies in early modern Venice,' in B. Blondé, E. Briot. N. Coquery and L. van Aert (eds.), Retailers and consumer changes in early modern Europe. England, France, Italy and the Low Countries (Tours: Presses Universitaires François-Rabelais, 2005) 170, 182; Belfanti and Giusberti, 'Clothing and social inequality in early modern Europe,' 361 , R.T. Rapp, Industry and economic decline in seventeenth century Venice (Cambridge: Harvard University Press, 1976) 103; R. Mackkenney, Tradesmen and traders. The world of guilds in Venice and Europe, c.1250-c.1650 (London: Croom Helm) 9o97, 102-111. 
market boomed in all main towns, bringing a great range of attire within easier reach and responding quickly to consumers' changing tastes.

The increasing demand for a wide range of consumer goods and a growing fashion sensitivity affected strategies of theft. Research on eighteenth-century Antwerp and Rotterdam suggests that thieves' loot included all sorts of popular clothing and luxury items, such as neckerchiefs, lace caps, stockings and aprons made of silk or cotton. ${ }^{101}$ Although unprocessed fabrics such as linen and cotton were also frequently stolen in Antwerp, relatively new goods, intended for resale, were especially popular. Apparel stolen in England was also described as in many instances epitomizing "elements of style and the lure of elite fashions."102 Court depositions in Bologna also allude to the demand for popular goods such as aprons and other garments. Some of these clothes were in used conditions, others brand new. Some were dyed into more fashionable colours to increase their resale value, ${ }^{103}$ while the immediate appeal of other garments can readily be understood, such as the white and grey damask skirt and the silk iridescent gown with pink details and silver embroidering that Maria Cantelli was accused of stealing in $1725 .{ }^{104}$

Patterns of theft did not only reflect consumption patterns, but were also contingent on dynamics of gender. In the historiography it is commonly assumed that the thefts of men and women differed regarding types of stolen goods, value, venue, mode and motivation. ${ }^{105}$ Various studies have stressed the distinctiveness of women's larcenous activities, tying their thefts to their traditional association with providing food for the family and direct household consumption. ${ }^{106}$ A notable example of this is Barbara Hanawalt's study of female felons in fourteenth-century England dating from the late 1970s. She argued that women primarily stole grain, clothing and household goods of low value,

101 Van der Heijden, Women and crime, 71-72; M. Vanbellinghen, 'Diefstal en heling van kleding en textiel: Antwerpen, 1775-1785,' Tijdschrift voor sociale geschiedenis 21:4 (1995) 387 .

102 Lemire, 'The theft of clothes and popular consumerism,' 258, 265.

103 ASBo, Torrone, 7077-2, fasc. 1.

104 АSво, Torrone, 7859-2, fasc. 51.

105 Beattie, 'The criminality of women,' 89-96; O. Ulbricht, 'Einleitung. Für eine Geschichte der weiblichen Kriminalität in der Frühen Neuzeit oder: Geslechtergeschichte, historische Kriminalitätsforschung und weibliche Kriminalität,' in O. Ulbricht (ed.), Von Huren und Rabenmüttern. Weibliche Kriminalität in der Frühen Neuzeit (Cologne/Weimar/Vienna: Böhlau, 1995) 19.

106 Spierenburg, 'How violent were women?,' 13; McEwan, 'Negotiating support,' 159; J. Philips and A.N. May, 'Female criminality in 18th-century Halifax,' Acadiensis 31:2 (2002), n.p. Retrieved from <https://journals.lib.unb.ca/index.php/Acadiensis/article/view/10721/ 11437>. 
reflecting the economic interests of women since their preoccupation was with the home. ${ }^{107}$ Since then, various scholars have challenged this binary distinction. Both Walker (for seventeenth-century Cheshire) and subsequently Dean (for late medieval Bologna) have suggested that men and women generally stole the same kinds of items and that the value of the goods stolen by women was not necessarily lower than those stolen by men. ${ }^{108}$

The types of goods that were stolen in seventeenth- and eighteenth-century Bologna support the notion that some of the patterns of theft were not as gender specific as was commonly believed. The criminal court records reveal that clothing, clothing accessories and textiles were among the most commonly stolen items (figure 8). The category of 'clothing' consisted of items such as aprons, capes, coats, busts, skirts, dresses, shirts, stockings and shoes and constituted the largest category of stolen items. The category of 'textiles' includes household linen, raw materials and assorted textiles such as silk and cotton found around houses and shops. Together, about 37 per cent of the theft cases brought before Bologna's criminal court concerned these kinds of textiles. In other towns in early modern Europe clothing also ranked high among the items that were stolen. ${ }^{109}$

Women were not the only ones with an eye for the value of linens and clothing. Historiographically the prevalence of these types of items among women's spoils is commonly portrayed as the outcome of their specific social and economic roles, their prominence in the less formal trading networks of second-hand domestic goods and pawnbroking and their subsequent knowledge about these types of goods. ${ }^{110}$ However, the Torrone's casebooks suggest that clothing, household linen and a variety of miscellaneous textiles were about as important for female defendants as for their male counterparts: about onethird were accused of stealing these types of goods. The situation laid out by the criminal court records thus provides little quantitative evidence for the

107 Hanawalt, 'The female felon in fourteenth-century England,' 262; Hanawalt. Crime and conflict, 122 .

108 Walker, Crime, gender and social order, 159-209; G. Walker, 'Women, theft and the world of stolen goods,' in J.I. Kermode and G. Walker (eds.), Women, crime and the courts in early modern England (London 1994) 81-105; Dean, 'Theft and gender,' 399-415.

109 Hufton, The poor in eighteenth-century France, 259; Beattie, Crime and the courts in England, 187;J.A. Sharpe, Crime in seventeenth-century England: a countystudy (Cambridge: Cambridge University Press, 1983) 91-114.

11 Walker, 'Women, theft and the world of stolen goods,' 88-89, 94, 97; Gray, Crime, prosecution and social relations, 76, 89; L. MacKay, 'Why they stole. Women in the Old Bailey, 17791789,' Journal of social history 32:3 (1999) 629, 633; S. Howard, 'Investigating responses to theft in early modern Wales. Communities, thieves and the courts,' Community and change 19 (2004) 421; Kilday, “'Criminally poor?," 515. 


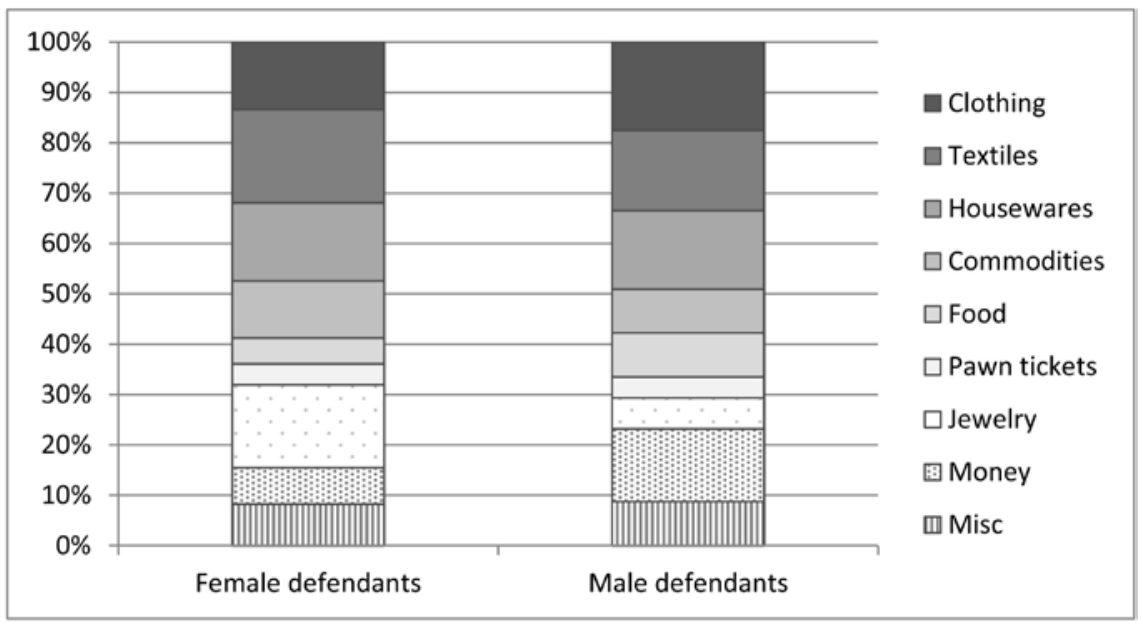

FIGURE 8 Stolen goods by gender of the offender, ca. $1655^{-1755}$

Calculations are based on the thefts captured in denunciations and processi with a total of 56 female defendants and 199 male defendants. Housewares: e.g. furniture, pots and pans, plates, vases, kettles. Commodities: e.g. raw materials, metals, building materials, tools and knives.

SOURCE: SAMPLES 2 AND 3 (SEE APPENDIX)

notion that the theft of clothing and household linen was a particularly gendered activity in early modern Bologna.

The general and pervasive theft of clothing and textiles speaks to the importance of these goods within the early modern material culture and plebeian commercial circuits. ${ }^{111}$ Probate inventories from seventeenth-century Rome, for example, show that clothing formed the bulk of the possessions of both men and women. ${ }^{112}$ Similarly, together with household linens, clothing consisted of the most important category of stolen goods Europe-wide. ${ }^{113}$ They were relatively easy to steal and conceal, were very expensive and were among

111 Term coined by B. Lemire, 'Plebeian commercial circuits and everyday material exchange in England, c. 16oo-19oo,' in B. Blondé, P. Stabel, J. Stobart and I. van Damme (eds.), Buyers \& sellers. Retail circuits and practices in medieval and early modern Europe (Turnhout: Brepols, 2006) 245; I. Cecchini, 'A world of small objects: Probate inventories, pawns and domestic life in early modern Venice,' Renaissance and Reformation. Special issue: The material culture of debt 35:3 (2012) 47 .

112 R. Ago, 'Il linguaggio del corpo,' in C.M. Belfanti and F. Giusberti (eds.), Storia d'Italia. Annali 19. La moda (Turin: Enaudi, 2003) 120.

113 Van der Heijden, Women and crime, 71; Walker, 'Women, theft and the world of stolen goods,' 87 . 
the most sought-after and easily disposable commodities since people outside of the higher ranks largely depended on used garments to clothe themselves. ${ }^{114}$ Second-hand clothing, whether acquired legally or illegally, therefore had guaranteed value and was assured of sale in early modern economies. ${ }^{115}$ In a city like Bologna, in which a large group of its inhabitants worked in the textile industry, this value was apparently recognised by male and female thieves alike.

While the Bolognese criminal court records testify to a great demand for clothing and other textiles, they also reveal a significant demand for a range of other types of goods. Most of these goods were as important to female offenders as to their male counterparts. Domestic goods such as furniture, plates, vases and kettles made up about one-fifth of the goods stolen in Bologna and were of equal importance to offenders of both sexes. A range of work tools (hammers, knives, tailor's scissors and so forth), building materials, metals and raw materials are counted among the category of commodities and consisted of one-eighth of the total items pilfered in the city by men and women alike. Similarly, one in twenty thefts concerned pawn tickets for either jewellery, clothing or household linens. Pawns could be redeemed by bringing the funds of the loan and the interest and the copy of the pawn slip (scrittarino) to the monte. As the amount of the loans was usually one-half to two-thirds of the assessed value of the pawn, collecting and selling the pawned objects on the markets could be a lucrative endeavour. ${ }^{116}$

Some differences between the extent to which male and female offenders stole certain kinds of items are noticeable. Food was more commonly stolen by male offenders than by their female counterparts. This category consisted both of actual foodstuffs such as beans, meats, fish, bread, fruits and agricultural produce such as wheat and grain, and of a range of animals such as chickens, horses, cows, sheep, oxen, goats and donkeys. About one in ten of the male offenders were accused of stealing goods in this category, while this was only the case for one in twenty female thieves. Lastly, money and jewellery were also regularly stolen. Jewellery like gold, silver and coral necklaces rings and pearls figured more prominently among the loot of female thieves (16 per cent) than

\footnotetext{
114 Hohti, "Conspicuous' consumption and popular consumers,' 666; Lemire, 'The theft of clothes and popular consumerism,' 256-257.

115 Lemire, 'The theft of clothes and popular consumerism,' 265.

116 M. Carboni, 'Converting goods into cash: An ethical approach to pawnbroking in early modern Bologna,' Renaissance and Reformation. Special issue: The material culture of debt 35:3 (2012) 71; M.G. Muzzarelli, 'From the closet to the wallet. Pawning clothes in Renaissance Italy,' Renaissance and Reformation. Special issue: The material culture of debt 35:3 (2012) 25 .
} 
men's (six per cent). The opposite is true for money, which made up 14 per cent of the goods pilfered by male defendants and only half that by their female counterparts.

The similarities between the pilfering propensities of men and women are significant and are indicative of a world of production and exchange in which both women and men played important roles. Some differences in what was stolen do emerge, notably regarding the theft of money and jewellery. A closer look at the court records suggests interesting contextual differences between these two types of cases. Jewellery and money were commonly taken from trunks and cupboards at home by the victims' neighbours or acquaintances, while money was also stolen from other types of places: pickpocketed while traversing night-time streets, from taverns and from shops, commonly by men whom the victims did not know or did not know well or not at all. While the difference between what men and women stole should not be overstated, it is imperative to examine the extent to which the spatial and social contexts of thieving were gendered.

Scholars generally agree that the criminal activities of men and women were shaped by the geographic and social boundaries of their everyday lives. By extension, it has been assumed that the geographies of theft must have been distinctly gendered because of the different opportunities that men and women had. ${ }^{117}$ The importance of houses and the immediate neighbourhood as spaces for women's violence has already been discussed - not as a separate domestic sphere, but as sites where conflicts arose from their quotidian labour and social relations. Thieving also appears to have primarily occurred within the same environs.

Bologna's geography of theft entailed a broad range of locations: from homes and shared spaces within the apartment complexes, to workshops, markets, mills, granaries, theatres and churches. Theft from residential locations was the most prevalent (see table 23). This most commonly concerned apartments or rooms rented or owned by victims, and the variety of goods stolen from this residential environment was broad: ranging from clothing, household linen, jewellery and domestic commodities such as furniture, pans and pots, to foodstuffs, money and pawn tickets. Many of these thefts were highly opportunistic, as is illustrated by the case against Giuseppe Carboni, who was 
taken for questioning by the chief constable for his involvement in theft. ${ }^{118} \mathrm{Gi}$ useppe admitted that he had seized the opportunity to take away two copper vases when his neighbour Marina Landi had left the door to her house unlocked. Similarly, in 1675 Girolama Negrini, a married chestnut seller, had also stolen a large copper vase worth 9 lire when her neighbour Violanta had left her front door wide open. ${ }^{119}$ To a lesser degree bolognesi also stole from the shared spaces within the apartment buildings, such as clothing hung to dry in courtyards and hallways. ${ }^{120}$ All in all about one-third of accused male thieves and nearly three-quarters of their female counterparts are reported to have stolen from people's domiciles. For female offenders, the importance of houses was thus even more prominent than among reported acts of violence.

The aforementioned examples also speak to the important role of neighbours in theft from houses in early modern Bologna. Both in historiographical treatments of thieving and contemporary anxieties it was not this neighbourpersona that took centre stage, but the domestic servant. ${ }^{121}$ Because domestic servants had access to every corner of the house and could easily incorporate thefts in their everyday work routines, their crimes were considered an important breach of trust. Due to this perceived betrayal, harsh sentences were prescribed for domestic theft (furto domestico) all over early modern Europe. ${ }^{122}$ Indeed, when the sbirri in Bologna retrieved a bed sheet domestic servant Anna Leandri had stolen from her employer from underneath her mother's bed, it comes as no surprise that he described in his denunciation that he was wondering what else she might have taken from him in the past. ${ }^{123}$ Yet, contrary to what both legislation and contemporary fears may suggest, domestic servants do not at all appear to have been in the majority among those stealing from houses: only one in six were employed as maidservants in these specific households. Instead, nearly half of the houses were pilfered by fellow tenants and neighbours, like Giuseppe and Girolama.

118 ASBo, Torrone, $7869-2$, fasc. 26.

119 ASBo, Torrone, 7035 , fasc. 3 .

120 See, for example, ASBo, Torrone, $7044-2$, fasc. 2.

121 For Germany, see Rublack, The crimes of women in early modern Germany, 93; for France: C.C. Fairchilds, Women in early modern Europe, 1500-1700 (Harlow: Pearson Education, 2007) 289; for England: Gray, Crime, prosecution and social relations, 89; McEwan, 'Negotiating support,' 161, 164-165, 169.

M. Neale, 'Property crime in late eighteenth-century Bristol. Contexts of theft in the premodern city' (Unpublished PhD thesis, University of Leicester, 2012) 141; Rublack, The crimes of women in early modern Germany, 99-100; Fairchilds, Women in early modern Europe, 289; Bando generale Serbelloni 1756, 44-46.

ASB o, Torrone, 8171-2, fasc. 22. 
TABLE 23 Locations of theft in denunciations and processi where known, ca. 1655-1755

\begin{tabular}{|c|c|c|c|c|c|c|c|c|}
\hline \multirow[b]{2}{*}{ House $^{a}$} & \multicolumn{2}{|c|}{ Female defendant } & \multicolumn{2}{|c|}{ Male defendant } & \multicolumn{2}{|c|}{ Total known } & \multicolumn{2}{|c|}{$\begin{array}{l}\text { Unidentified } \\
\text { offenders }^{c}\end{array}$} \\
\hline & 40 & $74 \%$ & 62 & $33 \%$ & 102 & $42 \%$ & 84 & $41 \%$ \\
\hline Shop & 1 & $2 \%$ & $5^{1}$ & $27 \%$ & $5^{2}$ & $24 \%$ & 72 & $35 \%$ \\
\hline Tavern & 1 & $2 \%$ & 18 & $10 \%$ & 19 & $8 \%$ & 6 & $3 \%$ \\
\hline Street/market & 6 & $11 \%$ & 37 & $20 \%$ & 43 & $18 \%$ & 26 & $13 \%$ \\
\hline $\begin{array}{l}\text { Public } \\
\text { buildingb }\end{array}$ & 6 & $11 \%$ & 20 & $11 \%$ & 26 & $11 \%$ & 18 & $9 \%$ \\
\hline Total & 54 & 100 & 188 & $100 \%$ & 242 & $100 \%$ & 206 & $100 \%$ \\
\hline
\end{tabular}

SOURCES: DERIVED FROM SAMPLE 2A, 2 B AND 3 (SEE APPENDIX), COUNTED BY DEFENDANT

a Also includes adjoining gardens, shared apartment hallways and courtyards

b Includes public buildings and structures such as churches, city gates, theatres, mills, granaries and stables

c Represents minimum counts; each case without suspect is counted here as one offender

Workshops, where goods were made and displayed to be sold, took second place among the most prominent locations of theft. At least a quarter of all reported thefts occurred in these places. Sometimes merchandise such as fabric, handkerchiefs, shoes, clocks and weapons were stolen from the display; a window that could be turned into a vending table. This happened on the 22nd of April 1705, when cobbler Appolinaro Guidi saw a carpenter's apprentice take off with a pair of shoes made from black cow leather he had placed in his shop's display. ${ }^{124}$ Other times, money or tools were stolen from shopkeepers when they were not looking or had temporarily left the room. Baker Pietro Babina, for example, complained that the two brassmakers Gaetano Bovina and Gregorio Gamini had deceived his assistant Giuseppe by claiming that they had lost a buckle mesh in the cellar and asked him to assist Gregorio in finding it. ${ }^{125}$ When Giuseppe left the shop to do so, Gaetano saw his chance to steal 10 to 12 paoli. Most common were night-time break-ins, resulting in the theft of anything from textiles, money, pottery, work tools such as hammers, scales and cooking utensils to pieces of furniture. Whether at night or during the day, stealing from shops was decidedly more common among male than for female defendants (27 compared to two per cent). This corresponds with

124 ASBo, Torrone, 76o8-1, fol. 101.

125 ASBo, Torrone, 8171-1, fol. 265. 
what is known for elsewhere in Europe, where cases concerning women's shoplifting only surged from the late-eighteenth century onwards under the influence of the so-called retailing revolution. ${ }^{126}$

A substantial part of the male thieves stole from other commercial spaces such as markets. Here a wide range of commodities - from foodstuffs and clothing to jewellery and tools - were stolen from the stalls displaying the market vendor's wares or from the baskets the street sellers used to transport their goods. Within this context, the victims were generally unacquainted with the thieves, who regularly only found out they were missing some of their merchandise some time after the fact. It was for example only by chance that market vendor Maria Annunziata, wife of Domenico Macchiavelli, found out who had stolen a brass scale from her market stall. She did not know who the men who stole from her were, but an acquaintance of hers had seen it happen and recognised local tailor Marco Boni and cobbler Angelo Nanni as the culprits. ${ }^{127}$ While none of the female thieves in the sampled Bolognese court records were accused of stealing from markets, this example underlines that this does not mean that women were absent from these spaces. Aside from the examples of women's violent encounters in these marketplaces discussed in the previous chapter, their presence as buyers and sellers, as bystanders and victims of theft, was widely recorded in the criminal court records.

Places of sociability such as taverns also provided opportunities for theft. About one in ten of the thefts took place here. As spaces where people gathered to drink, eat and gamble, inebriated visitors commonly lost their capes, money and jewellery to thieving hands in these osterie. ${ }^{28}$ They were also places where travellers received lodging. Because rooms and even beds were shared among strangers, personal items such as clothing and money were relatively easily misappropriated without the security of a locked room or trunk. ${ }^{129}$ When a 65-year-old Franciscan friar spent the night in one of Bologna's taverns, he woke up to find his money missing. ${ }^{130}$ He started complaining to the innkeeper that the foreigners in his room must have taken it. When interrogated by the criminal court's notary Agostino Grossi, a former servant from Modena who slept in the same bed as the friar, admitted that he had stolen the

126 S.G. Tickell, 'Shoplifting in eighteenth-century England' (Unpublished PhD thesis, University of Hertfordshire, 2015) 45-46; T.C. Whitlock, Crime, gender and consumer culture in nineteenth-century England (London/New York: Routledge 2016) 127-133. ASBo, Torrone, 8171-2, fasc. 15 .

128 АSво, Torrone, 7869-1, fol. 154; 7869-1, fol. 256; 8171-1, fol. 43; 8171-1, fol. 244.

129 ASBo, Torrone, 6620, fol. 105; 7028, fol. 133 .

13 о АSBo, Torrone, 7028-2, fasc. 15. 
money and had hidden it between the bed sheets to "serve his needs." ${ }^{31}$ Guests furthermore stole goods that belonged to the tavern. On 22 August 1705, the proprietor of the hosteria dei due Gamberi located near to Bologna's largest square accused Antonio Romagnoli from Imola of stealing two bed sheets. ${ }^{132}$ All in all, taverns featured more prominently as settings for thefts by men than for women (10 compared to two per cent). The normative and legal requirement of 'respectable' women to be accompanied to the tavern by male kin may have affected this outcome. ${ }^{133}$ While this again does not mean that women were absent from taverns, their opportunities to steal in these spaces were likely circumscribed compared to men's.

Counted here among various public buildings in Bologna, about one in twenty thefts by both male and female offenders occurred in churches and other religious buildings. Here money, jewellery, clocks and clothing items were stolen from fellow churchgoers, but the theft of books, goblets, paintings and vases from churches and oratories themselves was more important. After climbing the wall of a convent in the inner-city parish of San Isaia, the unemployed Sabatino Stanzani had taken two water vases and a copper washbowl. ${ }^{134}$ Similarly, Carlo Antonio Scagliarino stole a painting from the church of San Stefano after mass. ${ }^{135}$ While everybody was leaving, he hid the painting under his coat and sold it to a seller of used goods for 40 bolognini. Finally, about one in twenty thefts had taken place in Bologna's mills, granaries and stables. On 21 November 1705 Giuseppe Guidazzoli, for example, was accused of entering the granary of Lazaro Sarti through a window during the night and taking away two sacks of wheat. ${ }^{136}$ Other items that were reportedly taken from these places were such commodities as grain and flour, work tools, and animals such as horses, cows and chickens.

The landscape of theft in early modern Bologna was decidedly gendered. What stands out is the overwhelming importance of houses as locations for women's thefts. About two-thirds of the female defendants were accused of stealing from a room, apartment or within the apartment building in which the victim lived. While houses also featured prominently among men's geographies of theft, the proportional share of houses was less than half that of women's. Men were also much more likely than women to steal in a wide range of other spaces, such as the street, markets and taverns. It seems likely that this

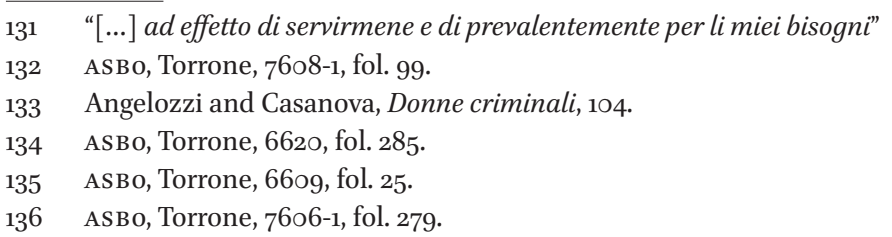


gendered pattern of thieving reflects the differences in legitimate social and economic opportunities. After all, both women's work and sociability were centred more in these spaces than men's, echoing the importance of the neighbourhood for women's everyday legitimate and illegitimate behaviours.

\section{6}

\section{The Distribution of Stolen Goods}

While the overwhelming majority of thieves who were brought under the criminal court's purview had no known criminal co-offenders, the redistribution of their stolen goods in society had nearly always involved a range of other actors. After all, despite associations between theft and poverty, registered thefts in which direct consumption played a role appear to have been rare. Most of the cases that came before the Torrone involved the reselling of goods. Even Maria Resonagli, who describes herself as a poor unfortunate person ( $p o-$ vera sventurata) who sold her "body to survive," did not intend to consume the chickens she was accused of stealing. Instead, she had planned to sell them to an innkeeper through an intermediary. ${ }^{137}$ On the other hand, just as foodstuffs could be sold rather than eaten, luxury items could be sold to buy bread and wine. ${ }^{138}$ While the relationship between theft and economic hardship was complex, some form of commercial exchange played an important role in nearly all cases brought before the criminal court.

It is commonly assumed that there was significant overlap between illegal economic traffic and legal early modern markets. ${ }^{139}$ Scholars have contended that goods were not only largely stolen from but were also redistributed through offenders' ordinary, legitimate social and economic networks. ${ }^{140}$ Since the geographies of theft in early modern Bologna appear to have differed for male and female offenders, this raises the question of whether the redistribution of stolen goods was also distinctly gendered. To this end, table 24 shows the locations of the sale of stolen goods. Out of the enhanced sample of property offending, only the cases against 66 male and 17 female offenders

\footnotetext{
137 АS Bo, Torrone, 8179-2, fasc. 25 .

138 ASBo, Torrone, 66o9, fol. 25; 6620, fasc. $1 ; 7044$, fasc. 11.

139 Lemire, 'Plebeian commercial circuits,' 245, 254; Lemire, 'The theft of clothes and popular consumerism,' 256-257.

140 Walker, 'Women, theft and the world of stolen goods,' 81-105, MacKay, 'Why they stole,' 623-639, Callahan, 'On the receiving end,' 106-121; Howard, 'Investigating responses to theft,' 409-430.
} 
shed light on the commercial journey of the goods that they were accused of stealing. ${ }^{141}$ While the small sample size precludes us from drawing any statistically sound conclusions, these criminal court dossiers nevertheless provide an indication of how stolen goods found their way back into the urban economy of early modern Bologna.

For the mid-seventeenth to mid-eighteenth century, the Bolognese criminal court records suggest that workshops and tradesmen may have been the most important nodes in the redistribution of stolen goods. In about a third of the cases, stolen goods were disposed of through such shops and/or tradesmen. These stolen wares commonly were commodities they needed and used in their everyday occupation. As such, stolen fabric was turned over to tailors, silver and gold items to goldsmiths, flour to bakers and tin and copper pots and pans to tinsmiths. ${ }^{142}$ The prominence of these businesses among illegal circuits has also been noted for eighteenth-century Bristol, where victuallers, carpenters, alehouse keepers, silversmiths, blacksmiths and other tradesmen readily (though purportedly unknowingly) purchased stolen property as part of their everyday business. ${ }^{143}$

In spite of their key roles in the distribution of stolen goods, it is unclear to what degree shopkeepers and tradesmen were aware of their unlawful origins. In order not to be treated and prosecuted as accomplices, the criminal bylaws stipulated that buyers should always inquire about the origins of both the seller and the goods. ${ }^{144}$ In the sampled thefts there is only one example of a coppersmith who refused to buy two copper vases from two contadini (farmers) because he wanted to know who the two sellers were exactly as an assurance of good sale. ${ }^{145}$ The court records indicate that it was fairly common to forgo persistent queries. Miller Domenico Ciapelli, for example, ground the grain that the temporarily unemployed bricklayer Gio Batta Consini had stolen, but excused his actions by saying he had not had a clue where Gio Batta had got the grain from because he simply had not asked him. ${ }^{146}$ Gio Batta then sold the flour on to a baker for three bolognini. The baker in turn denied knowing that he had been offered stolen goods, although he also admitted never really in-

141 My sample includes another 211 theft cases for which it was entirely unknown who the offenders were. These are excluded from this examination as they never reveal information about what happened to the stolen goods.

143 M. Neale, 'Making crime pay in late eighteenth-century Bristol: Stolen goods, the informal economy and the negotiation of risk,' Continuity \& change 26:3 (2011) 445.

144 Angelozzi and Casanova, Donne criminali, 96; Bando generale Serbelloni 1756, 53-55.

145 ASBo, Torrone, 6620, fol. 285.

146 Asвo, Torrone, 66og, fasc. 2. 
TABLE 24 Locations of sale of stolen goods by identified defendants, ca. 1655-1755

\begin{tabular}{lccccc}
\hline & $\begin{array}{c}\text { (Work)shop/ } \\
\text { tradesman }\end{array}$ & Reseller & Pawn bank & $\begin{array}{c}\text { Unspecified } \\
\text { individuals }\end{array}$ & Total \\
\hline Male defendants & 25 & 16 & 13 & 12 & 66 \\
Female defendants & 4 & 5 & 2 & 6 & 17 \\
Total & 29 & 21 & 15 & 18 & 83 \\
\hline
\end{tabular}

SOURCE: DERIVED FROM SAMPLE 2A, 2B AND 3 (SEE APPENDIX)

quiring about it. Apparently the court officials were reluctant to convict tradesmen of malicious intent when performing their quotidian commercial activities, as only very few of the sampled Bolognese receivers were found guilty. ${ }^{147}$

Acquiring used goods was an essential part of the business of second-hand dealers, who made up the second most important role in the distribution of stolen goods. In Bologna, about a third of the female thieves and a quarter of their male counterparts disposed of stolen goods through such second-hand dealers. Because the vast majority of inhabitants lived a hand-to-mouth existence, the flourishing second-hand markets were pivotal in enabling ordinary people to obtain all kinds of domestic goods that would otherwise have been out of their reach. ${ }^{148}$ Alongside local shopkeepers, a variety of second-hand dealers (rigattieri, treccole or rivenditori/trici) were key players in this kind of trade. ${ }^{149}$ While these resellers sold a wide range of used goods, clothing and household linen figured prominently among the commercial journeys of stolen goods unearthed by the Torrone.

147 The sample includes 27 accused men and 7 women for whom it can be deduced from the sources that they played roles as 'receivers of stolen goods.' More buyers of stolen goods were mentioned and interrogated as part of the criminal records, but they were not formally accused. For five of the indicted receivers their fate was unknown, 13 were absolved and nine were bound to re-appear before the court if new information came up. Four men and one woman were pardoned (the original sentences were not always recorded: one man was originally sentenced to 5 years of imprisonment, and a woman to exile). Two men received guilty verdicts and were exiled.

148 Hohti, 'Conspicuous' consumption and popular consumers,' 66o. For an overview of scholarship on this topic from early modern England, France, and Scotland, see P. Allerston, 'Reconstructing the second-hand trade in sixteenth- and seventeenth-century Venice,' Costume 33:1 (1999) 46.

Hohti, "Conspicuous' consumption and popular consumers,' 659. 
Women played vital roles in these second-hand markets. While the sampled criminal court cases do not suggest a vast difference between male and female offenders in their choice to dispose of goods via a second-hand dealer, their role as distributors appears to have been significant. Information about the share of women among second-hand dealers in early modern Bologna is scarce, not least because second-hand dealers' guilds in most Italian cities formally excluded women. ${ }^{150}$ The repeated decrees of measures seeking to contain and control female sellers nevertheless speak to their constant presence in the fabric of urban life. ${ }^{151}$ Remarkably, a close reading of the court records suggest that about half of the second-hand dealers that had handled the stolen goods investigated by the Bolognese criminal court had been women. Most of these female resellers are only known to us because they provided witness testimonies in the case, and a serious consideration of their possible malintent appears to be lacking. The significant role that these women played stands in stark contrast to the fact that they represented only one in five of the (admittedly few) receivers accused by the Torrone. The involvement of the other female resellers was limited to providing witness testimonies. This not only sheds light on the prevalence of female resellers in the urban economy of early modern Bologna, particularly in the second-hand clothes markets, but the fact that so many of them were not even indicted - let alone prosecuted - for their role may additionally reveal a certain judicial 'indulgence' towards women also observed for female thieves with co-offenders.

Another way to dispose of stolen goods was through pawn banks. Pawn banks emerged from the fifteenth century onwards in towns and cities across central and northern Italy. ${ }^{152}$ Promoted by travelling preachers and run by lay religious groups, they provided low-cost credit to the working poor by allowing the poor to monetise the value stored in their moveable possessions. Bologna's Monte di pietà (literally a 'mountain of piety') opened in April of 1473, closed again the year after and, then backed by the ruling oligarchy, was revived in December 1504 as a civic bank with different agencies spread over the city's quarters and became one of the most successful pawn-broking institutions in Italy. ${ }^{153}$ Based on the number of pledges, it has been calculated that there were

150 A. Meneghin, 'The trade of second-hand clothing in fifteenth-century Florence: Organisation, conflicts, and trends,' in G. Nigro (ed.) Il commercio al minuto. Domanda e offerta tra economia formale e informale. Secc. XIII-XVIII. Selezione di ricerche (Florence: Firenze University Press, 2015) 328.

151 Welch, Shopping in the Renaissance, 35-36.

$15^{2}$ N. Terpstra and M. Carboni, 'Introduction,' Renaissance and Reformation. Special issue: The material culture of debt 35:3 (2012) 6; Muzzarelli, 'From the closet to the wallet,' 23 .

Carboni, 'Converting goods into cash,' $64-65$. 
nearly two pawns per inhabitant in Bologna by the mid-seventeenth century. ${ }^{154}$ The majority of customers were artisans, shopkeepers and, above all, lowskilled (day) labourers. ${ }^{155}$ While few households had many surpluses of goods, they nevertheless had many pawnables that functioned as a small, material reserve for times of need. As such, by lending on the security of pawns, the pawn banks performed a major countercyclical function in local economies. ${ }^{156}$ They also constituted an important node in more illegal circuits of exchange. Between the mid-seventeenth and mid-eighteenth centuries, the Torrone was able to trace a little over one in six of the stolen wares back to Bologna's monte.

All in all, the criminal court records highlight the importance of ordinary and legitimate markets for the disposal of stolen goods. In early modern Bologna, workshops and their tradesmen, second-hand dealers and civic pawn banks played pivotal roles in both legal and illegal commercial activities for both male and female thieves. Unfortunately, the criminal court records often shed little light on the commercial journeys of these stolen goods, for example because the defendants kept denying involvement and there were no witnesses who reported having seen or heard about the stolen goods. It is therefore also difficult to ascertain if and to what extent the patterns of distribution were as distinctly gendered as the geography of theft appears to have been itself. While outside of the scope of this research, more in-depth examinations of the social networks of thieves may be fruitful. After all, there are important indications Italian women played vital roles in the distribution of stolen goods, yet by and large escaped scrutiny by the authorities. Gendered notions of culpability may well have clouded their appearance as criminal actors in property offences.

\section{7 Conclusion: Judicial Paternalism and Women's Roles in Thieving}

The pattern of reported crime in early modern Italian towns was extensively moulded by its everyday violence, rather than larcenous activities. Yet thefts were not infrequent occurrences and, importantly, were by no means considered futilities by either its victims or the authorities. While the criminal court records brim with acts of petty violence as part of conflict resolution strategies, thefts of all shapes and sizes were among the 'serious crimes' that the court

\footnotetext{
154 Ibidem, 66.

155 Ibidem, 78. The ledgers of Tuscan pawn banks paint a similar image, see P. Pinelli, "Illegal" pawns for "immoral" loans; Testing the limits of the Monti di Pietà in late fifteenth-century Tuscany,' Renaissance and Reformation. Special issue: The material culture of debt 35:3 (2012) 14 .

156 Carboni, ‘Converting goods into cash,' 64; Terpstra and Carboni, 'Introduction,' 8.
} 
sought to investigate and prosecute if in any way possible. This overall interest in prosecuting these kinds of crimes is not only apparent in the harsh sentences that the criminal bylaws prescribed, but also in the fact that thefts made up larger shares among the formal investigations (processi) than among the denunciations. This was especially true for women, who were above all subjected to a formal investigation not for their acts of violence but for theft.

Women's larcenous activities in early modern urban Bologna was distinct from men's in some ways but also shared many important characteristics. For one, both male and female offenders were by and large accused of committing the same type of offence - simple theft without resorting to violence - which was overwhelmingly committed by only one offender: rather than being confined to the role of accomplices, no less than two-thirds of the female Bolognese offenders committed thefts on their own. Male and female defendants also resembled each other in a socioeconomic sense: belonging to the large group of the labouring poor who, as textile workers, and market vendors, resorted to opportunistic theft to make shift. The Torrone's casebooks furthermore suggest that what men and women stole - most commonly clothing, household linen and miscellaneous textiles - was not as distinctly gender specific as is often suggested. That the experiences of male and female offending were nevertheless gendered is above all apparent when scrutinising the geography of theft. Just as women's violence predominantly erupted between neighbours in their immediate neighbourhood vicinity, no fewer than eight out of ten of women's thefts (compared to 41 per cent of men's) were also committed from houses by neighbours and acquaintances. This echoes the importance of the neighbourhood for women's legitimate and illegitimate everyday behaviours.

For early modern Italian towns like Bologna it is furthermore important to highlight the impact of its legal culture on the judicial treatment of theft, and affected the proportion of women among thieves, which was significantly lower in Italy than it was in many other places in early modern Europe. ${ }^{157}$ While crimes against property - however small in value - could rely on more judicial scrutiny than most acts of violence in early modern Italy, the criminal court records reveal that the culture of reconciliation also pervaded the ways thefts were dealt with. Renunciations and pardoning after peacemaking were less often achieved for property offences than for violent crimes, they were

157 Noordam, 'Strafrechtspleging en criminaliteit,' 228; Old Bailey Proceedings Online (<https://www.oldbailey online.org/>, version 7.2, March 2015), Tabulating offence category, between 1674 and 1800 . Counting by defendant; Morgan. and Rushton, Rogues, thieves and the rule of law, 6o; Schwerhoff, Historische Kriminalitätsforschung, 116. 
nevertheless pivotal to the understanding of how crimes against property were dealt with in early modern Italy. Moreover, the judicial treatment of theft was also highly gendered. Emanating from a body of law that viewed male criminals as the norm, the gendered notions of appropriate and suitable punishments are a straightforward example of this. Where the galleys or torture via the strappado were deemed appropriate for offending men, confinement, exile or lashing was regarded as more suitable for their female counterparts. Importantly, a gender bias also led to women being treated more leniently in court. Particularly when women acted alongside male co-offenders, they could count on less harsh sentences or were not even indicted at all. The criminal court records furthermore suggest that by far most of the women involved in the distribution of stolen goods into the urban economy were never scrutinised as criminal actors in the first place.

Women's involvement in theft was both nebulous and pervasive. As criminal actors in a serious crime, the Bolognese criminal court records suggest significantly smaller shares of women among recorded property offenders than in many other regions in early modern Europe. While the evidence of women's everyday violent behaviours can be traced through the use of the criminal justice system as a forum for conflict resolution, our image of women's involvement in theft is contingent on the authorities' efforts to investigate and indict them. Alongside a range of factors such as the interlocking semi-charitable institutions for 'problematic' women and the social control exercised by the head of the family, the traces of judicial paternalism further uncover how women in early modern Italy were kept away from the law and the law away from women. ${ }^{158}$ Rather than interpreting these silences as proof for early modern Italian women's lack of agency, they more than anything testify to the idea that these unusual suspects only represented a tip of the iceberg.

$15^{8}$ Sbriccoli, 'Deterior est condicio foeminarum,' 83-84. 